\title{
A Systematic Review of Meta-Analyses that Evaluate Risk Factors for Dementia to Evaluate the Quantity, Quality, and Global Representativeness of Evidence
}

\author{
Kaarin J. Anstey, ${ }^{\mathrm{a}, \mathrm{b}, *}$, Nicole Ee $\mathrm{a}^{\mathrm{a}, \mathrm{b}}$, Ranmalee Eramudugolla ${ }^{\mathrm{b}}$, Carol Jagger ${ }^{\mathrm{c}}$ and Ruth Peters ${ }^{\mathrm{a}, \mathrm{b}}$

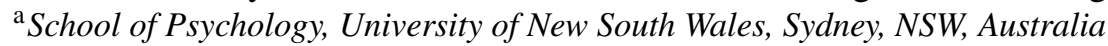 \\ ${ }^{\mathrm{b}}$ Neuroscience Research Australia (NeuRA), Sydney, NSW, Australia \\ ${ }^{\mathrm{c}}$ Newcastle Institute for Ageing, Newcastle University, Newcastle, UK
}

Accepted 20 May 2019

\begin{abstract}
.
Background: The translation of evidence on dementia risk factors into clinical advice requires careful evaluation of the methodology and scope of data from which risk estimates are obtained.

Objective: To evaluate the quantity, quality, and representativeness of evidence, we conducted a review of reviews of risk factors for Alzheimer's disease (AD), Vascular dementia (VaD), and Any Dementia.

Methods: PubMed, Cochrane library, and the Global Index Medicus were searched to identify meta-analyses of observational studies of risk factors for AD, VaD, and Any Dementia. PROSPERO CRD42017053920.

Results: Meta-analysis data were available for 34 risk factors for AD, 26 risk factors for Any Dementia and eight for VaD. Quality of evidence varied greatly in terms of the number of contributing studies, whether data on midlife exposure was available, and consistency of measures. The most evidence was available for cardiovascular risk factors. The most geographically representative evidence (five of six global regions) was available for alcohol, physical activity, diabetes, high midlife BMI, antihypertensives, and motor function. Evidence from Australia/Oceana or Africa was limited. With the exception of diabetes, meta-analysis data were unavailable from Latin America/Caribbean. Midlife specific data were only available for cholesterol and arthritis.

Conclusion: There is a lack of midlife specific data, limited data on $\mathrm{VaD}$, and a lack of geographical representation for many risk factors for dementia. The quality, quantity, and representativeness of evidence needs to be considered before recommendations are made about the relevance of risk factors in mid- or late-life or for dementia subtypes.
\end{abstract}

Keywords: Alzheimer's disease, cohort studies, meta-analysis, prevention, risk factor, vascular dementia

\section{INTRODUCTION}

Dementia prevalence will continue to increase due to population aging and will cause a significant burden of disease [1], unless the onset of dementia is

\footnotetext{
${ }^{*}$ Correspondence to: Prof. Kaarin J. Anstey, PhD, School of Psychology, University of New South Wales, Sydney, New South Wales, 2052, Australia. Tel.: +61 29399 1019; E-mail: k.anstey@unsw.edu.au.
}

delayed [2]. Older adults commonly have dementia of mixed pathology that is amenable to modification by treatment of vascular risk factors. Therefore, data on risk factors for dementia is increasingly used to inform national preventative health policy as illustrated by the recent publication of evidence reports $[3,4]$. However, the evidence base to support recommendations for dementia risk reduction falls short of what is a growing demand by the 
scientific community for reproducibility of methods and results. The 2017 Lancet Commission report [4] made recommendations for risk reduction based on two sources: a United States Government Report published in 2010 [5]; and the United Kingdom National Clinical Practice Guidelines (NICE guidelines) [6], which provided a narrative review of the literature. It concluded that childhood education, exercise, maintaining social engagement, reducing smoking, and management of hearing loss, depression, diabetes, and obesity are key risk factors which collectively have the potential to delay or prevent a third of dementia cases [4]. The recent United States National Academies' Consensus Report focused on systematic reviews of interventions, and identified cognitive training, hyper/hypotension and physical activity as reducing dementia risk but that evidence for these was only modest [3]. There has been limited quantitative evaluation of the volume, quality, and generalizability of the body of observational evidence available for putative risk factors for dementia. Global recommendations have been based on findings drawn from narrow geographical regions and with limited age range. Evaluating the breadth and depth of a body of evidence allows for clarification of evidence gaps, areas of bias, and provides a bird's eye view of the field [7]. We therefore aimed to conduct a novel umbrella systematic review of the observational evidence for risk factors for dementia to produce an overview of the global evidence in the field, focusing on the types of information required to underpin the development of clinical practice guidelines [8]. We evaluate both the quantity of evidence and its representativeness, and identify areas of bias resulting from pooling of results in meta-analyses.

\section{MATERIALS AND METHODS}

\section{Search strategy and eligibility criteria}

A systematic review of reviews was conducted [9], and pre-registered in PROSPERO CRD42017053920. PubMed, the Cochrane Library, and the Global Index Medicus (which covered LILACS, WPRIM, IMEMR, IMSEAR, WHO IRIS, AIM, MedCarib) (inception to 8, September 2018) and reference lists of retrieved articles were also manually searched and content experts in the field were consulted for other relevant publications.

The following search strategies were employed: PubMed/Medline: ((risk OR "protective factors"
[Mesh]) OR precipitating factors[MeSH Terms]) OR ((prevention and control[MeSH Terms]) OR risk factors[MeSH Terms]) OR etiology[MeSH Terms]) OR epidemiology[MeSH Terms])) AND (dementia OR alzheimer's OR alzheimers OR alzheimer OR “dementia”[Mesh] OR "cognitive dysfunction" [Mesh] OR healthy brain OR brain health)) AND (meta-analysis OR meta-analyses) AND systematic[sb]); Cochrane Library: \#1: $\mathrm{MeSH}$ descriptor: [Dementia] explode all trees; \#2: $\mathrm{MeSH}$ descriptor: [Mild Cognitive Impairment] explode all trees;\#3: MeSH descriptor: [Causality] explode all trees; \#4: MeSH descriptor: [Epidemiologic Factors] explode all trees; \#5: \#1 or \#2; \#6: \#3 or \#4; \#7: \#5 and \#6 in Other Reviews; Global Index Medicus: mh:( "Alzheimer Disease" OR "Dementia, Vascular" OR "Dementia”)) AND (mh:("Risk Factors" OR "Causality" OR "Epidemiologic Factors; PsycINFO:

1 exp Protective Factors/ (4806)

2 exp Etiology/or exp Risk Factors/or exp Epidemiology/ (142956)

3 exp PREVENTION/ (55681)

4 cognitive dysfunction.mp. (5918)

5 alzheimer's disease.mp. or exp Alzheimer's Diseasel (55884)

6 exp DEMENTIA/ or DEMENTIA.mp. (90379)

7 risk.mp. (346369)

8 (meta-analysis or meta-analyses). $m p$. [ $m p=$ title, abstract, heading word, table of contents, keyconcepts, original title, tests \& measures] (30891)

91 or 2 or 3 or 7 (438985)

104 or 5 or $6(101538)$

118 and 9 and 10 (618)

12 limit 11 to "0830 systematic review" (121)

13 limit 12 to $y r=$ "1860 - 2018” (120)

Any systematic review of a risk factor for Alzheimer's disease (AD), Vascular dementia (VaD), or Any Dementia was eligible. Reviews were excluded if they specified their primary outcome was early-onset dementia/familial AD. Only reviews of longitudinal studies were included. If a pooled estimate contained cross-sectional and longitudinal data, hazard ratios for longitudinal primary studies were extracted and risk ratios re-pooled. Reviews were excluded if the majority of primary studies obtained dementia diagnoses from medical records solely, if they included primarily clinical samples, did not report inclusion and exclusion criteria, did not conduct meta-analyses, or were not published in peer-reviewed journals, so as to exclude low quality 
reviews. Non-English publications were translated with Google Translate.

\section{Data screening and extraction}

Citations of all publications returned by the search strategies were screened for duplicates and remaining reviews screened in two further stages. At least two independent reviewers rated each article; inconsistencies in decisions on inclusion were resolved through discussion and consensus. Abstracts were screened for relevance and where there was insufficient information available for a decision, they were tentatively included. All remaining publications underwent fulltext review for assessment against inclusion and exclusion criteria.

Data extracted for potential meta-analysis and narrative review included: risk exposure measured at midlife $(<65$ years) or late-life $(65+$ years); dementia outcome (AD, VaD [10], and Any Dementia which, potentially included $\mathrm{AD}, \mathrm{VaD}$, dementia with Lewy bodies, frontotemporal dementia/Pick's disease, alcohol related dementia, mixed and other dementias); study design (sample source, number of participants, observation period), sample characteristics (country, percentage female, average age of participants included in the review, age range, average years of education), risk factor reviewed, number of studies, measurement of dementia or cognition, unadjusted and adjusted estimates of association, hazard ratio (HR), relative risk (RR), beta, $p$-values with $95 \%$ confidence intervals $(\mathrm{CI})$, and $\mathrm{I}^{2}$. From each article, we extracted the number of individual studies included in each meta-analysis, and the specific study details to allow for evaluation of how many studies were included in multiple meta-analyses, as well as the continent/region in which the original data were collected (North America, Europe, Asia/Middle East, Australia/Oceana, Africa, Latin America).

\section{Quality assessment}

The quality of evidence was evaluated at three levels: risk factor, meta-analysis (i.e., per pooled risk estimate), and publication and was informed by the literature on factors that affect the quality of evidence as identified by the GRADE initiative [11] and tailored specifically to dementia epidemiology. For example, AD pathology accumulates over decades and the prodromal period may last several years so that the significance of the length of exposure to a risk factor must be interpreted taking this into account.

\section{Risk factor evidence quality}

'Body of Evidence Metrics (BEM)' (Table 1) were developed based on the premise that a strong body of evidence for supporting dementia prevention programs across the world would draw from study populations that represent a wide range of countries and ethnicities, and include: mid- and late-life risk factors; information on the relationship of the risk factor to $\mathrm{AD}, \mathrm{VaD}$, and Any Dementia; high quality systematic reviews of sufficient sample size and length of follow-up, with consistently defined exposure and outcome measures. Ideally, the body of evidence would be based on recent studies, particularly for a risk factor that may be susceptible to history and cohort effects.

\section{Quantity and recentness of evidence}

1. Quantity of primary studies: The number of primary studies included per meta-analyses (n) (Table 1), the total number of unique primary studies per risk factor $(\mathrm{N})$, and degree of overlap in inclusion of studies within individual meta-analyses $(R=\mathrm{n} / \mathrm{N})$ (Supplementary Table 1) were recorded.

2 . Recency of reviews was calculated as the percentage of reviews published within the last five years (since 2013) for a given risk factor.

\section{Exposure}

3. Quality of exposure measure (Table 1): Use of standard definitions and variability of measures used for each risk factor and commentary on type of measure (e.g., categorical, scale). This metric evaluates variation in the consistency of exposure measures that are pooled in meta-analyses.

\section{Outcome}

4. Outcome measure as clinical diagnosis: the percentage of reviews that did or did not use a standard clinical outcome measure (i.e., Diagnostic and Statistical Manual, the International Classification of Diseases, and other widely used classification systems or Consensus criteria published by groups of experts).

5. Subtypes of dementia represented (AD, VaD, Any Dementia).

\section{Population}

6. Primary baseline age-group represented per risk factor (midlife 40-59; late-life 60+; and percentage of studies in which baseline age is unknown) [4].

7. Range of follow-up (Table 1) and percentage long-term follow-up: For each risk factor, the 
Table 1

Body of Evidence Metrics: Representativeness, quality and quantity of evidence per risk factor

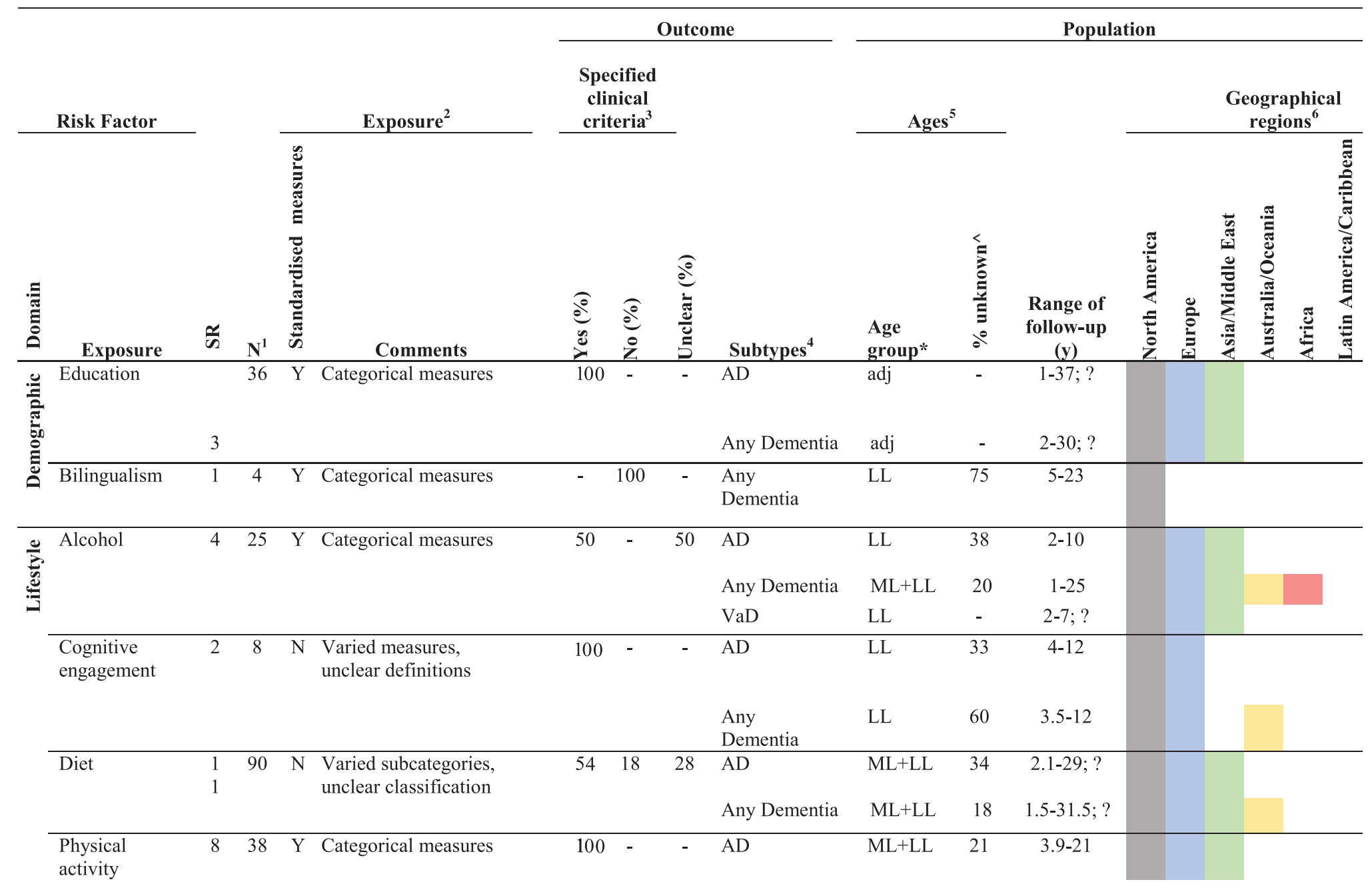




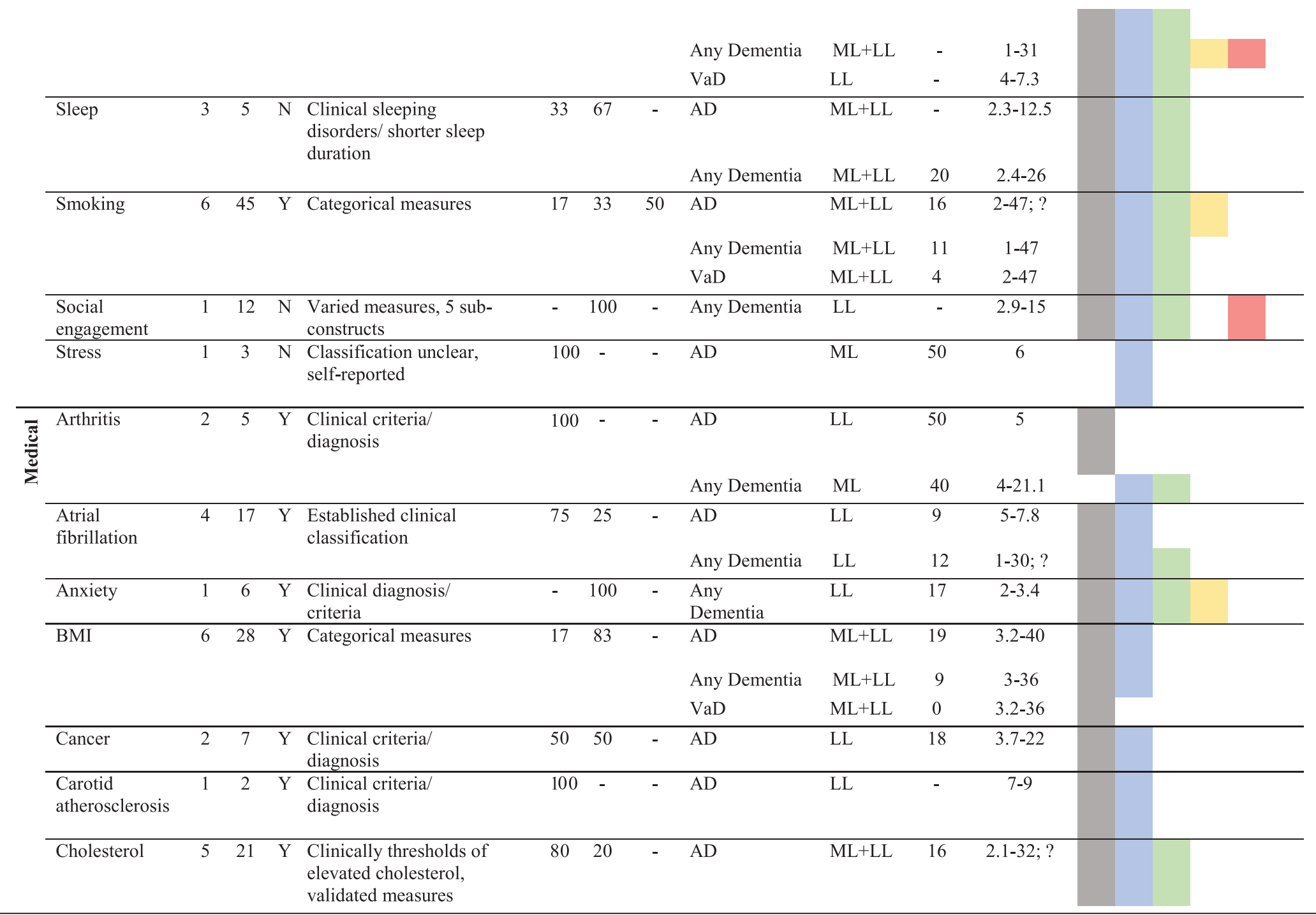




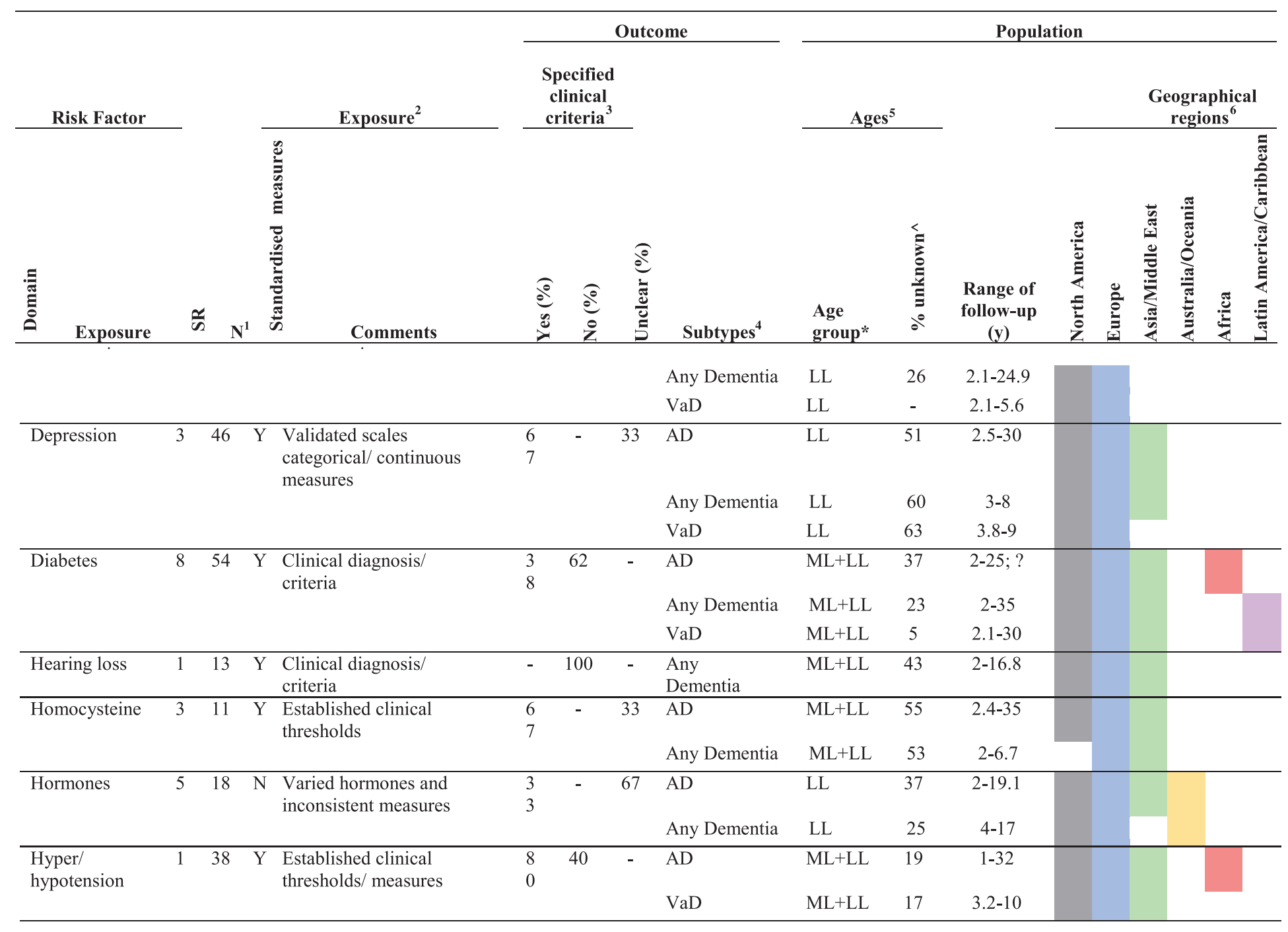




\begin{tabular}{|c|c|c|c|c|c|c|c|c|c|c|c|}
\hline $\begin{array}{l}\text { Inflammatory } \\
\text { markers }\end{array}$ & 1 & 4 & $\mathrm{Y}$ & Established biomarkers & - & - & 100 & $\begin{array}{l}\text { AD } \\
\text { Any Dementia }\end{array}$ & $\begin{array}{l}\text { LL } \\
\text { LL }\end{array}$ & 21 & $\begin{array}{l}6-25 \\
4-25\end{array}$ \\
\hline $\begin{array}{l}\text { Metabolic } \\
\text { syndrome }\end{array}$ & 1 & 4 & $\mathrm{Y}$ & $\begin{array}{l}\text { Established clinical } \\
\text { thresholds/ measures }\end{array}$ & 100 & - & - & $\mathrm{AD}$ & LL & 25 & $3-4.4$ \\
\hline Motor function & 1 & 10 & $\mathrm{~N}$ & Varied measures & - & - & 100 & $\begin{array}{l}\text { Any } \\
\text { Dementia }\end{array}$ & $\mathrm{LL}$ & - & $3.8-13.6$ \\
\hline $\begin{array}{l}\text { Peripheral } \\
\text { artery disease }\end{array}$ & 1 & 2 & $\mathrm{Y}$ & $\begin{array}{l}\text { Established clinical } \\
\text { thresholds/ measures }\end{array}$ & 100 & - & - & $\mathrm{AD}$ & $\mathrm{LL}$ & 50 & $5-5.4$ \\
\hline Renal disease & 1 & 3 & $\mathrm{Y}$ & $\begin{array}{l}\text { Established clinical } \\
\text { thresholds/ measures }\end{array}$ & 100 & - & - & $\mathrm{AD}$ & LL & 67 & $6-7.5$ \\
\hline $\begin{array}{l}\text { Serum uric } \\
\text { acid }\end{array}$ & 1 & 3 & $\mathrm{~N}$ & $\begin{array}{l}\text { Established clinical } \\
\text { thresholds/ measures }\end{array}$ & - & 100 & - & $\mathrm{AD}$ & $\mathrm{LL}$ & - & $3-11.1$ \\
\hline Stroke & 2 & 10 & $\mathrm{Y}$ & Clinical diagnosis & 100 & - & - & $\mathrm{AD}$ & LL & 43 & $3-9$ \\
\hline TBI & 3 & 15 & $\mathrm{Y}$ & $\begin{array}{l}\text { Established clinical } \\
\text { thresholds/ measures }\end{array}$ & 33 & 67 & - & $\begin{array}{l}\text { AD } \\
\text { Any Dementia }\end{array}$ & $\begin{array}{l}\mathrm{LL} \\
\mathrm{ML}+\mathrm{LL}\end{array}$ & $\begin{array}{l}57 \\
50\end{array}$ & $\begin{array}{c}1.2-14.5 \\
?\end{array}$ \\
\hline Antacids & 1 & 2 & $\mathrm{Y}$ & Established drug class & - & - & 100 & $\mathrm{AD}$ & $?$ & 100 & $5-20$ \\
\hline $\begin{array}{l}\text { Antihypertensi } \\
\text { ves }\end{array}$ & 6 & 23 & $\mathrm{Y}$ & Established drug class & 33 & 33 & 33 & $\mathrm{AD}$ & $\mathrm{ML}+\mathrm{LL}$ & 30 & $2.2-32$ \\
\hline & & & & & & & & $\begin{array}{l}\text { Any } \\
\text { Dementia }\end{array}$ & $\mathrm{ML}+\mathrm{LL}$ & 13 & $2.2-32$ \\
\hline $\begin{array}{l}\text { Anti- } \\
\text { inflammatories }\end{array}$ & 4 & 17 & $\mathrm{Y}$ & Established drug class & 100 & - & - & $\mathrm{AD}$ & ML+LL & 21 & $<1-30$ \\
\hline Benzodiazepines & 1 & 2 & $\mathrm{Y}$ & Established drug class & 100 & & & $\begin{array}{l}\text { Any } \\
\text { Dementia }\end{array}$ & $?$ & 100 & $?$ \\
\hline
\end{tabular}


Table 1

(Continued)

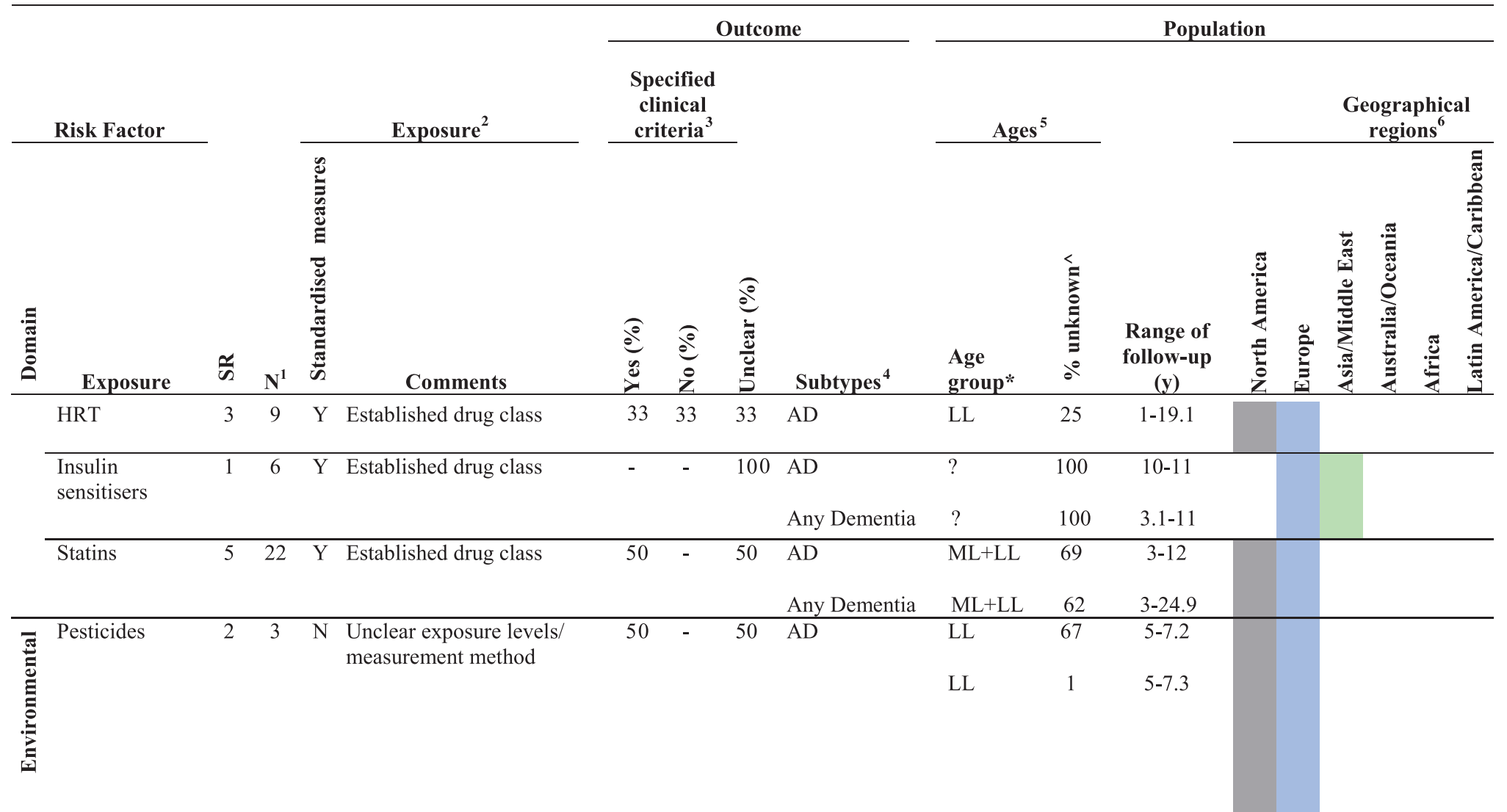

Note. SR denotes no. of systematic reviews identified, *the primary ages represented, 'adj' denotes age-adjusted (baseline age is not relevant to measures of self-reported educational attainment), 'ML' denotes midlife (baseline age $<65$ ), 'LL' denotes late-life (baseline age $65+$ ), '?' denotes unknown. $\wedge$ is the percentage of primary studies where baseline age is not reported, and "Env." is environmental. ' $\mathrm{Y}$ ' denotes yes and ' $\mathrm{N}$ ' denotes no. Body of Evidence Metrics. ' 'N' denotes the quantity of evidence per risk factor; total number of primary studies for each risk factor ${ }^{2}$ Indicates standardization and variability of exposures measures within risk factors. ${ }^{3}$ The percentages of identified reviews which did or did not have specified clinical diagnosis as an inclusion criteria, or where this was not reported. ${ }^{4}$ Subtypes of dementia represented: AD, VaD, any. ${ }^{5}$ Ages groups represented, primary age group, and $\%$ of primary studies where age group is not reported. ${ }^{6}$ Geographical regions represented. 
number of primary studies with lengths of follow-up in the following categories: $<5$ years, 5-9.9 years, 10-19.9 years, and 20+ years, or unknown length of follow-up was identified. The percentage of primary studies with long follow-up periods (i.e., ten or more years follow-up) was reported. Length of follow-up is important because dementia has a long prodromal period, so shorter studies have increased risk of reverse causality.

8. Geographical regions: global generalizability (see Table 1 and see Fig. 2), number of regions represented across all estimates in risk factor/ total of six possible regions $\times 100$. Risk of bias when generalizing findings in relation to a risk factor is increased if the majority of evidence is derived from a single geographical area.

\section{Meta-analysis quality}

A representativeness statistic was calculated using number of primary studies pooled per risk estimate divided by the total number of primary studies per risk factor. Lower scores indicate that the meta-analysis is reporting a smaller proportion of the available evidence base for that risk factor. It is expected that older meta-analyses would have a lower representativeness statistic and more recently published meta-analyses have a higher statistic (detailed summary on individual meta-analyses and pooled risk estimates in Supplementary Table 1). A validated measure of evidence overlap for meta-analyses termed Corrected Covered Area (CCA \%) [12] was estimated for each risk factor and is reported in Supplementary Table 5, and associated interpretive descriptors are represented in Fig. 3.

\section{Publication quality}

Risk of bias of included reviews were rated using the AMSTAR scale [13] (Supplementary Table 3). AMSTAR provides rating of domains of potential bias and is not intended to be used as a total score. Studies included are listed in Supplementary Table 4.

\section{Data synthesis and analysis}

Data were collated and synthesized with a summary provided according to risk factor by age, i.e., exposure for midlife only, late-life only, or studies combining exposure in both. Results were also reported separately for $\mathrm{AD}$, Any Dementia, and $\mathrm{VaD}$ where data were available. Summary effect sizes and 95\% CI with fixed effects and random effects models for each meta-analysis were used to determine significance and size of study effects; between-study heterogeneity was assessed with $\mathrm{I}^{2}$ (the proportion of between-study variance to the sum of within- and between-study variances), which ranges from $0 \%$ to $100 \%$. Where meta-analyses contained non-prospective data or where $\mathrm{I}^{2}$ was not reported, individual study $\mathrm{HRs}$ and $95 \%$ CI were extracted. Summary estimates and $\mathrm{I}^{2}$ statistics were re-calculated using Meta-Analysis software version 3.0 and Stats Direct 3.1.

\section{RESULTS}

Of the 825 articles identified, 809 were screened and 203 reviewed at full-text of which 113 were deemed ineligible (reasons for exclusion provided in Supplementary Table 2). We identified 91 articles reporting meta-analyses that met criteria for our review (see Fig. 1), and these contained 271 pooled estimates for 36 risk factors for AD (Table 1), $\mathrm{VaD}$, and Any Dementia (study characteristics are reported in Supplementary Table 1). Risk factors were classified as demographic, lifestyle (including diet and nutrient factors which were grouped together), medical, pharmacological, or environmental. BEMs are reported in Table 1 and Fig. 2 (for AD). The number of unique primary studies included in systematic reviews for a given risk factor ranged from two (e.g., carotid atherosclerosis, peripheral artery disease, antacids) to 90 (e.g., diets) (Fig. 2 and Supplementary Table 1) with more than 40 studies included for smoking, depression, and diabetes, and 20-39 studies included for education, alcohol, physical activity, body mass index (BMI), cholesterol,

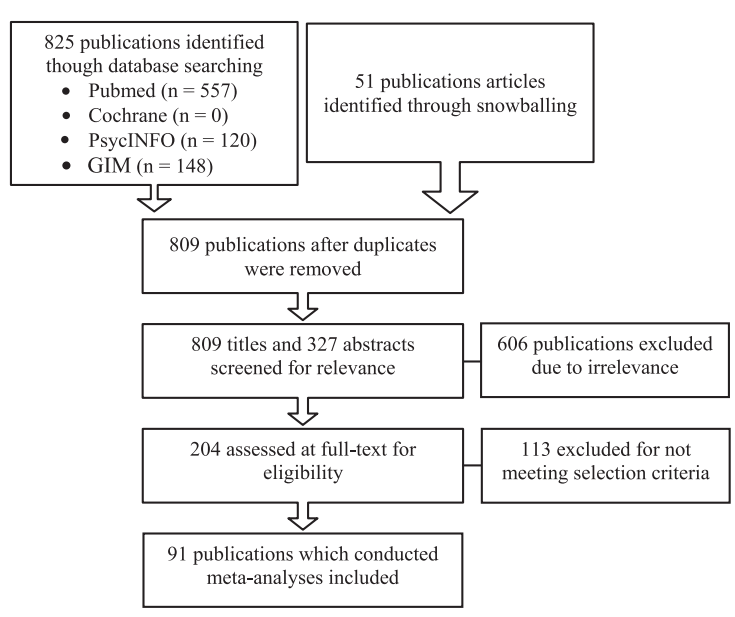

Fig. 1. Study identification and selection flow chart. 
Percentage of reviewed dementia risk factors for which evidence is available from different geographic regions of the world
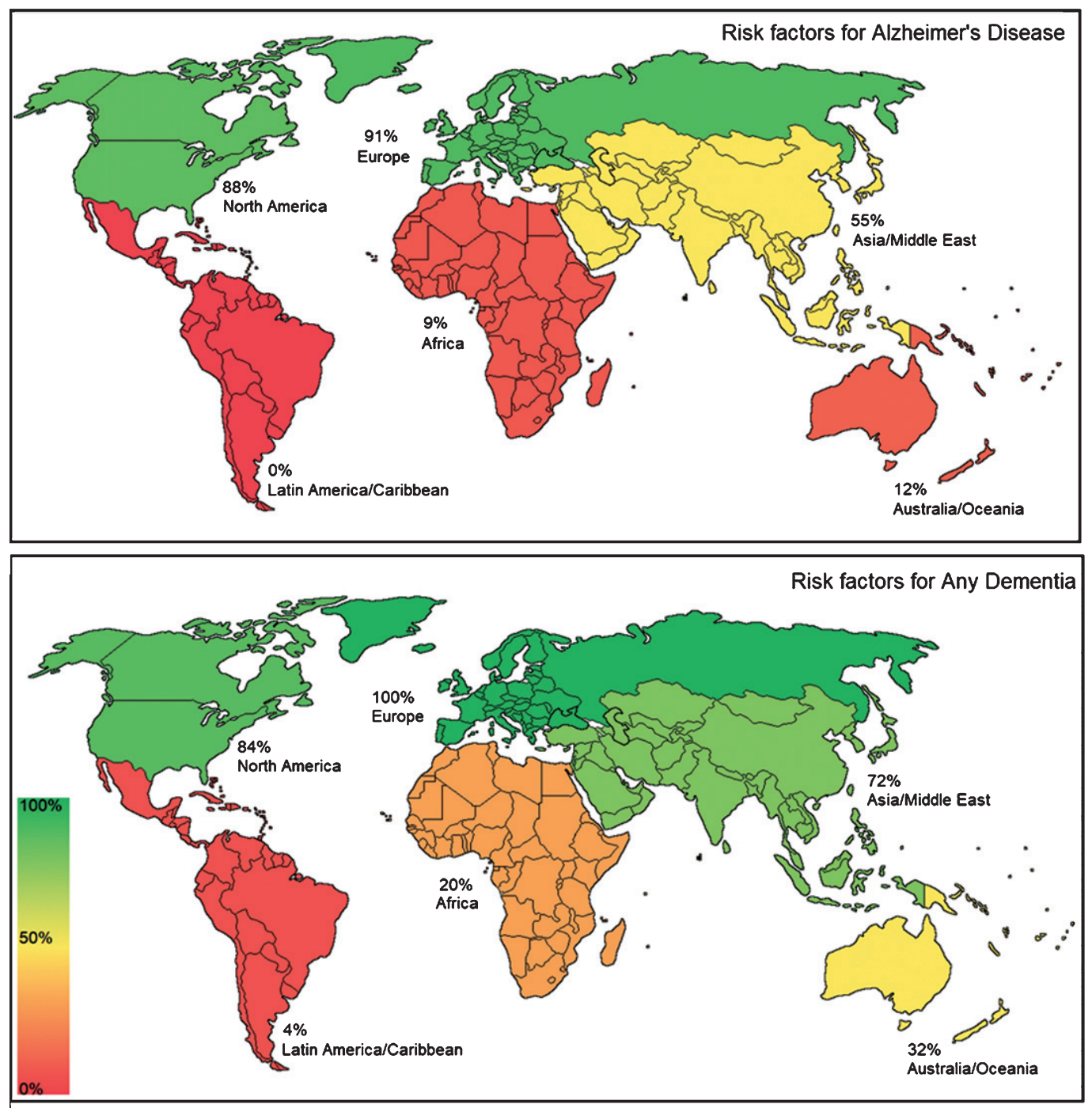

Fig. 2. World maps showing distribution of evidence on risk factors for Alzheimer's disease and Any Dementia.

hyper/hypotension, antihypertensives, and statins. CCA estimates indicated that degree of overlap between reviewed studies was highest for physical activity, diabetes, traumatic brain injury (TBI), cancer, stroke, statins, anti-inflammatories, hormone replacement therapy (HRT), and pesticides (Fig. 3). Risk factors with a high number of primary papers and frequency of reviews, but with slight to moderate CCA included: education, alcohol, diet, BMI, and atrial fibrillation. Fewer than five studies were identified for bilingualism, stress, carotid atherosclerosis, inflammatory markers, metabolic syndrome, peripheral artery disease, renal disease, serum uric acid, antacids, benzodiazepines, and pesticides. For around half of the risk factors, all the reviews included had been published in the last six years, in contrast to the risk factors of smoking, alcohol, and homocysteine where fewer than $40 \%$ of the reviews had been published within the past six years.

We found that individual meta-analyses did provide new and different information from each other. On average they reported a minority $27 \%$ of the total studies published per risk factor. This highlights the importance of considering the evidence per risk factor as a whole rather than relying on evidence from specific meta-analysis. In general, AMSTAR rating 
quality was higher for more recent reviews (Supplementary Table 3 ). The most common area where studies lost points was lack of a specified "a priori" research design (e.g., registered protocol) $(86 \%$ of reviews), and not providing a list of excluded studies ( $80 \%$ of reviews). It was assumed that protocols did not exist if not mentioned. Standard measures of exposures were lacking for cognitive engagement, diet, social engagement, stress, hormones, and pesticides, and risk factors varied greatly in the degree to which component meta-analyses used exposure measures consistently, e.g., meta-analyses of cognitive engagement included studies with exposure to high participation in cognitive activities, intellectual activities, and stimulating activities.

Around one quarter of the meta-analyses used standard outcome measures (Table 1). Reviews lacking a requisite clinical diagnosis criterion included dementia outcomes based on non-diagnostic measures like the Mini-Mental State Exam (MMSE), informant or self-report of medical history, or another nonstandard cognitive test. Meta-analyses of BMI and smoking had particularly low proportions $(<25 \%)$ of studies with specified clinical diagnostic criteria for dementia. Some meta-analyses (bilingualism, social engagement, sleep, anxiety, hearing loss, inflammatory markers, motor function, serum uric acid, antacids, and insulin sensitizers) did not report use of any standard outcomes or were unclear in their reporting. AD was the most common dementia subtype to be investigated as an outcome. Only $8 / 39$ risk factors were evaluated for $\mathrm{VaD}$. Social engagement, anxiety, hearing loss, and motor function have not been reviewed as risk factors for either $\mathrm{VaD}$ or $\mathrm{AD}$.

Where age-group was reported, the evidence on bilingualism, cognitive and social engagement, atrial fibrillation, anxiety, cancer, carotid atherosclerosis, depression, hormones, inflammatory markers, metabolic syndrome, motor function, peripheral artery disease, renal disease, serum uric acid, stroke, HRT, and pesticides is drawn from studies that commenced in later life only (Table 1). In this case, it is unclear whether these factors, when occurring in midlife, are associated with dementia risk. Age group was not reported for antacids, benzodiazepines, and insulin sensitizers. The evidence for all other risk factors included studies of middle-aged as well as older adults, though there were specific gaps in age coverage for dementia sub-types; for example, most meta-analyses of risk factors for $\mathrm{VaD}$ only included exposures measured in late-life.
The greatest proportion of evidence from long follow-up ( $10+$ years) was for motor function $(80 \%$ of studies), insulin sensitizers (75\% of studies), and bilingualism (75\% of studies) (range 3-23 years but missing data precluded estimate of proportion with long follow-up). Additional risk factors with at least a third of the evidence derived from long followup included insulin sensitizers $(75 \%)$, hearing-loss (70\%), sleep (60\%), BMI (57\%), antacids and serum uric acid (50\%), cancer (46\%), diabetes $(42 \%)$, cholesterol (41\%), smoking (40\%), education (33\%), and HRT (30\%) (see Fig. 3). In addition, 51\% of risk factors identified had reviews with incomplete reporting of study follow-up duration with, on average, follow-up durations being omitted for $25 \%$ of component studies. Risk factors with the least complete follow-up information include anti-inflammatories (87\% missing), benzodiazepines (100\% missing), and TBI ( $81 \%$ missing). Risk factors for which the body of evidence is based only on short term follow-ups ( $<10$ years) include carotid atherosclerosis, metabolic syndrome, peripheral artery disease, renal disease, serum uric acid, stroke, and pesticides. Those with the longest follow-up periods (40+ years) include smoking and BMI.

The most geographically representative evidence (covering five of six regions) was available for alcohol, physical activity, diabetes, motor function, and antihypertensives, followed by diet, smoking, social engagement, anxiety, hormones, and hyper/hypotension (four of six regions). Figure 2 shows the distribution of data on a map of the world with the most risk factor data drawn from Northern Europe.

There was no evidence from Asia/Middle East on bilingualism, cognitive engagement, stress, BMI, cancer, carotid atherosclerosis, inflammatory markers, metabolic syndrome, peripheral artery disease, antacids, benzodiazepines, anti-inflammatories, HRT, statins, and pesticides. Meta-analysis evidence from Australia/Oceana or Africa was relatively limited, and, with the exception diabetes, evidence from Latin America/Caribbean was unavailable.

Table 2 lists the 33 risk factors for AD for which meta-analyses were available, the number of studies contributing to each pooled risk estimate, the age of exposure (midlife or late-life), and the number of reviews contributing to results per risk factor. Egger's test was non-significant for most risk factors and results for heterogeneity were varied both between meta-analysis of the same risk factor and between risk factors. Nineteen risk factors had effect 
sizes drawn from more than five studies and had non-significant tests for bias or low to moderate heterogeneity $\left(\mathrm{I}^{2}<50 \%\right)$.

Significant associations with $\mathrm{AD}$ increased risk were found for clinical depression versus no depression (RR: $2.04(1.40,2.98)$ [14]), diabetes versus no diabetes (RR: $1.39(1.16,1.66)$ [15] to 1.57 $(1.41,1.75)[16])$, high BMI predominantly in midlife versus normal BMI (RR: $1.35(1.19,1.54)$ [17] to $2.04(1.59,2.69)$ [17]), low educational attainment versus high (RR: $1.32(1.09,1.59)$ [18] to $1.78(1.43,2.22)[19])$, high homocysteine ((RR:1.15 $(1.09,1.23)$ [20] to $2.50(1.38,4.56)$ [21]), smoking (RR:1.12 $(1.00,1.26)[22]$ to $1.99(1.33,2.98)$ [23]), depression increase risk per increase in depressive symptom (RR: $1.06(1.02,1.10)$ [14] to 1.65 $(1.42,1.92)[24])$, and decreased risk for NSAIDS (RR: $0.42(0.26,0.66)$ [25] to $0.74(0.57,0.97)$ [26]), alcohol (any or light/moderate versus abstinence) (RR: $0.43(0.17,0.69)$ [20] to $0.72(0.61$, 0.86 [ [27]), physical activity guidelines/more active versus inactive/less active (RR: 0.55 (0.36, 0.84) [28] to $0.80(0.69,0.94)$ [29]), fish (highest versus lowest) (RR: $0.64(0.44,0.92)$ [30] to $0.93(0.90$, $0.95)$ [31]), and coffee/caffeine intake versus no caffeine (RR: $0.69(0.47,0.90)$ [20] to $0.73(0.55,0.97)$ [32]). There was a mixed pattern of findings from meta-analyses of some risk factors, including statins, inflammatory markers, hyper/hypotension, and TBI. For the remaining risk factors (including cognitive activity, vitamin D deficiency, Mediterranean dietary pattern, stress, sleep, arthritis, carotid atherosclerosis, metabolic syndrome, serum uric acid), there was only one or a few systematic reviews and few contributing studies, thus providing insufficient evidence to draw even tentative conclusions (Table 2).

Figure 3 visually depicts the body of evidence metrics for all risk factors for all outcomes. The figure shows for example that for Bilingualism, data are recent, drawn from late-life with 10 years of exposure, based on 4 contributing studies in a single review, with most studies missing data on age of exposure. In comparison, the evidence for physical activity is drawn from 8 systematic reviews that include 35 cohort studies and include exposure in midlife and late life. Data on diabetes is drawn from 8 reviews that include a total of 54 studies, and includes information on midlife and late-life. Hence the body of evidence for physical activity and diabetes is far larger and covers a wider age-range than the evidence for bilingualism.
Of the 26 risk factors evaluated with Any Dementia as an outcome (Supplementary Table 1), those for which there was at least one individual meta-analysis of more than 20 studies were physical activity, smoking, and depression. Among meta-analyses for education and atrial fibrillation, the largest number of studies was 14 , for hearing loss, 13 , for statins, 12, and for antioxidants, 11. In meta-analyses of alcohol, coffee, fat, fish, vitamin C, D, and E intake, sleep social engagement, anxiety, BMI, hormones, TBI, antihypertensives, insulin sensitizers, the largest number of studies included was 5-10. All other meta-analyses included at most 2-4 studies. High educational attainment (highest quartile compared with reference quartile) (RR: 0.59 (0.41, 0.87) [19]) was associated with a lower risk of Any Dementia. Late-life alcohol consumption (light to moderate and any, compared with abstinence) (RR: 0.65 (0.54, $0.79)$ [33] to $0.74(0.61,0.91)$ [27]), statins used in $\mathrm{mid} /$ late-life versus no statins (RR: $0.71(0.61,0.96)$ [34] to $0.87(0.82,0.92)$ [35]) higher levels of physical activity (as compared to lower levels) (RR: 0.72 $(0.60,0.86)[28]$ to $0.86(0.76,0.97)[36])$, antihypertensives (RR: $0.79(0.70,0.89)$ [37] to $0.86(0.75$, 0.99) [38]) and antioxidants (RR: $0.87(0.77,0.98)$ [39]) and were associated with reduced risk of Any Dementia.

Cognitive engagement, Mediterranean diet, fish, fruit and vegetable, vitamin B and D, and tea drinking in mid- and late-life were associated with reduced risk but pooled estimates were derived from fewer studies (2-5 studies per estimate). Increased risk of Any Dementia was associated with insomnia (RR: 1.53 $(1.07,2.18)[40])(5$ studies with very high heterogeneity), shorter sleep duration as compared to longer sleep duration (RR: $1.42(1.15,1.77)$ [41]), low social engagement in late-life (RR: $1.41(1.13,1.75)$ [42] to $1.58(1.19,2.09)$ [42]) obesity (RR: $1.41(1.20$, 1.65) [43] to $1.91(1.41,2.62)$ [44]), underweight BMI in late-life (RR: $1.36(1.07,1.73)$ [45]), hearing loss (RR: 1.38 (1.23-1.53) [46]), low education (compared with higher levels of education) (RR: 1.32 $(1.09,1.59)[18]$ to $1.81(1.59,2.06)[19])$, and smoking (RR: $1.13(1.05,1.22)$ [22] to $1.43(1.15,1.77)$ [39]). Coffee/caffeine was not associated with risk of Any Dementia.

Eight risk factors were evaluated for $\mathrm{VaD}$ (Supplementary Table 1), and meta-analyses for which there were eight or more studies included: diabetes (RR:1.73 (1.61, 1.85) [47] to $2.49(2.09,2.97)$ [48]) and smoking (RR: $1.25(1.05,1.47)$ [22] to $1.78(1.28$, 2.47) [49]), with a single meta-analyses of six studies 
Table 2

Summary of AD studies by risk factor

\begin{tabular}{|c|c|c|c|c|c|c|c|}
\hline Risk Factor & Short reference & Exposure measure & Age group* & RR & $I^{2}(\%)$ & Bias (Egger's $p$ ) & $\bar{n}$ \\
\hline \multicolumn{8}{|l|}{ Demographics } \\
\hline \multirow[t]{4}{*}{ Education } & Xu 2016 [19] & $\begin{array}{l}\text { Lowest versus reference } \\
\text { quartile }\end{array}$ & adj & $1.78(1.43,2.22)$ & 36.0 & absent $^{\wedge}$ & 9 \\
\hline & Xu 2015 [20] & $\begin{array}{l}\text { Low }(<16 \text { y) versus high } \\
\quad(\geq 16 y)\end{array}$ & adj & $1.60(1.32-1.94)$ & 57.0 & 0.00 & 14 \\
\hline & $\begin{array}{l}\text { Caamano-Isorna } \\
2006[18]\end{array}$ & Lower versus highest levels & adj & $1.32(1.09,1.59)$ & absent & - & 9 \\
\hline & Xu $2016[19]$ & $\begin{array}{l}\text { Highest versus reference } \\
\text { quartile }\end{array}$ & adj & $0.44(0.32,0.60)$ & 41.5 & 0.018 & 10 \\
\hline \multicolumn{8}{|l|}{ Lifestyle } \\
\hline \multirow[t]{7}{*}{ Alcohol } & & Drinker versus non-drinkers & & & & & \\
\hline & Anstey 2009 [27] & Drinker versus non-drinkers & LL & $0.66(0.47,0.94)$ & 0.0 & $\sim$ & 2 \\
\hline & $\mathrm{Xu} 2015$ [20] & Ever versus never & $\mathrm{LL} / ?$ & $0.43(0.17,0.69)$ & 0.0 & 0.33 & 3 \\
\hline & Anstey 2009 [27] & $\begin{array}{l}\text { Heavy/excessive versus } \\
\text { non-drinker }\end{array}$ & LL & $0.92(0.59,1.45)$ & 0.0 & 0.22 & 3 \\
\hline & Xu 2015 [20] & High versus low/none & $\mathrm{LL} / ?$ & $0.96(0.18,1.74)$ & 78.8 & 0.56 & 3 \\
\hline & Xu 2015 [20] & $\begin{array}{l}\text { Light-moderate } \\
\text { consumption versus } \\
\text { non-drinkers }\end{array}$ & $\mathrm{LL} / ?$ & $0.61(0.54,0.68)$ & 0.0 & 0.44 & 5 \\
\hline & Anstey 2009 [27] & $\begin{array}{l}\text { Light to moderate versus } \\
\text { non-drinker }\end{array}$ & LL & $0.72(0.61,0.86)$ & 56.4 & 0.36 & 6 \\
\hline $\begin{array}{l}\text { Cognitive } \\
\text { engagement }\end{array}$ & Xu 2015 [20] & $\begin{array}{l}\text { High participation in } \\
\text { cognitive activity }\end{array}$ & $\mathbf{L L} / ?$ & $0.53(0.42,0.63)$ & 90.5 & 0.00 & 5 \\
\hline \multirow[t]{20}{*}{ Diet } & Singh 2014 [50] & $\begin{array}{l}\text { Adherence to } \\
\text { Mediterranean } \\
\text { diet-highest versus } \\
\text { lowest }\end{array}$ & LL & $0.64(0.46,0.89)$ & 0.0 & $\sim$ & 2 \\
\hline & Xu 2015 [20] & Caffeine/coffee drinking & $\mathrm{ML} / ?$ & $0.69(0.47,0.90)$ & 0.0 & 0.96 & 3 \\
\hline & Wu 2016 [51] & $\begin{array}{l}<1 \text { cup coffee per day } \\
\text { versus } 1-2 \text { cups }\end{array}$ & LL & $0.71(0.54,0.94)$ & 0.0 & 0.98 & 3 \\
\hline & Kim 2015 [52] & $\begin{array}{l}\text { Coffee intake-highest } \\
\text { versus lowest }\end{array}$ & LL & $0.71(0.52,0.97)$ & 0.0 & $\sim$ & 3 \\
\hline & Liu 2016 [32] & $\begin{array}{l}\text { Coffee intake-highest } \\
\text { versus lowest }\end{array}$ & $\mathbf{M L} / \mathbf{L L}$ & $0.73(0.55,0.97)$ & 0.0 & 0.80 & 4 \\
\hline & $\begin{array}{l}\text { Barranco } 2007 \\
\quad[53]\end{array}$ & $\begin{array}{l}\text { Coffee consumption versus } \\
\text { non-consumption }\end{array}$ & $?$ & $0.73(0.54,0.99)$ & 0.0 & $\sim$ & 2 \\
\hline & $\mathrm{Xu} 2015$ [20] & Fat, DHA & $\mathrm{LL} / ?$ & $0.76(0.52,1.11)$ & 68.3 & 0.04 & 4 \\
\hline & Wu 2015 [30] & $\begin{array}{l}\text { Fat, DHA/EPA-highest } \\
\text { versus lowest }\end{array}$ & LL & $0.89(0.74,1.08)$ & 36.3 & 0.01 & 3 \\
\hline & Xu 2015 [20] & Fat, EPA & $?$ & $0.96(0.75,1.16)$ & 0.0 & 0.25 & 3 \\
\hline & Zhang 2016 [31] & $\begin{array}{l}\text { Fat, DHA-0.1-g/d } \\
\text { increment }\end{array}$ & $\mathbf{M L} / \mathbf{L} \mathbf{L}$ & $0.63(0.51,0.76)$ & 94.6 & 0.10 & 3 \\
\hline & Zhang 2016 [31] & Fat, PUFA-8-g/d increment & ML/LL & $0.96(0.65,1.27)$ & $34.6 \%$ & - & 2 \\
\hline & Zhang 2016 [31] & Fat, EPA-0.1-g/d increment & ML/LL & $1.04(0.85,1.23)$ & 5.1 & 0.10 & 2 \\
\hline & Wu 2015 [30] & $\begin{array}{l}\text { Fish intake-highest versus } \\
\text { lowest }\end{array}$ & LL & $0.64(0.44,0.92)$ & 59.0 & 0.10 & 6 \\
\hline & Xu 2015 [20] & Fish intake & $\mathrm{LL} / ?$ & $0.66(0.43,0.90)$ & $64.7 \%$ & 0.54 & 6 \\
\hline & Zhang 2016 [31] & $\begin{array}{l}\text { Fish-increment of } 1 \\
\text { serving/wk }\end{array}$ & ML/LL & $0.93(0.90,0.95)$ & $74.8 \%$ & 0.174 & 5 \\
\hline & $\mathrm{Xu} 2015$ [20] & $\begin{array}{l}\text { Folate-high serum folate } \\
\text { levels }\end{array}$ & $\mathrm{LL} / ?$ & $0.51(0.29,0.73)$ & $16.0 \%$ & 0.29 & 4 \\
\hline & Kim 2015 [52] & $\begin{array}{l}\text { Tea intake-highest versus } \\
\text { lowest }\end{array}$ & LL & $1.12(0.83,1.50)$ & $0.0 \%$ & $\sim$ & 3 \\
\hline & $\mathrm{Xu} 2015$ [20] & Vitamin C intake & $\mathbf{L L} / ?$ & $0.74(0.55,0.93)$ & $0.0 \%$ & 0.19 & 6 \\
\hline & Xu 2015 [20] & Vitamin E intake & $\mathbf{L L} / ?$ & $0.73(0.62,0.84)$ & $0.0 \%$ & 0.81 & 6 \\
\hline & Shen 2015 [54] & $\begin{array}{l}\text { Vitamin D deficiency } \\
(25(\mathrm{OH}) \mathrm{D} \text { level }<50 \\
\text { nmol/L) }\end{array}$ & $\mathrm{LL} / ?$ & $1.21(1.02,1.41)$ & $0.0 \%$ & - & 2 \\
\hline
\end{tabular}


Table 2

(Continued)

\begin{tabular}{|c|c|c|c|c|c|c|c|}
\hline Risk Factor & Short reference & Exposure measure & Age group* & RR & $I^{2}(\%)$ & Bias (Egger's $p$ ) & $\bar{n}$ \\
\hline \multirow[t]{8}{*}{ Physical activity } & $\begin{array}{c}\text { Santos-Lozano } \\
2016[55]\end{array}$ & $\begin{array}{l}\text { Physically active (according } \\
\text { to international PA } \\
\text { guidelines: }>150 \\
\text { min/week of MVPA) } \\
\text { versus inactive }\end{array}$ & LL & $0.60(0.51,0.71)$ & $5.6 \%$ & 0.34 & 5 \\
\hline & Xu 2015 [20] & $\begin{array}{l}\text { High participation in } \\
\text { leisure-time PA }\end{array}$ & $\mathrm{LL} / ?$ & $0.65(0.46,0.84)$ & $81.0 \%$ & 0.09 & 10 \\
\hline & $\begin{array}{c}\text { Santos-Lozano } \\
2016[55]\end{array}$ & Higher versus lower PA & ML/LL & $0.65(0.55,0.75)$ & $39.3 \%$ & 0.83 & 9 \\
\hline & $\begin{array}{l}\text { Daviglus } 2011 \\
\quad[56]\end{array}$ & Higher versus lower PA & $?$ & $0.72(0.53,0.98)$ & - & - & 9 \\
\hline & Xu 2017 [29] & Higher versus lower PA & ML/LL & $0.80(0.69,0.94)$ & $0.0 \%$ & $\sim$ & 8 \\
\hline & Hamer 2009 [28] & Highest versus lowest PA & ML/LL & $0.55(0.36,0.84)$ & $79.5 \%$ & $<0.01$ & 6 \\
\hline & Beckett 2015 [57] & Highest versus lowest PA & ML & $0.61(0.52,0.73)$ & $0.0 \%$ & 0.02 & 9 \\
\hline & Xu 2017 [29] & Highest versus lowest PA & ML/LL & $0.74(0.58,0.94)$ & $46.3 \%$ & $\sim$ & 8 \\
\hline Sleep & Bubu 2016 [58] & $\begin{array}{l}\text { All sleep } \\
\text { problems/disorders listed } \\
\text { in International } \\
\text { Classification of Sleep } \\
\text { Disorders versus none }\end{array}$ & ML/LL & $1.47(1.28,1.69)$ & $66.9 \%$ & 0.79 & 6 \\
\hline \multirow[t]{10}{*}{ Smoking } & Zhong 2015 [22] & Current versus never & LL & $1.40(1.13,1.73)$ & $66.8 \%$ & $<0.01$ & 12 \\
\hline & Anstey 2007 [49] & Current versus former & $\mathbf{L L} / ?$ & $1.70(1.25,2.31)$ & $0.0 \%$ & 0.70 & 4 \\
\hline & Anstey 2007 [49] & Current versus never & $\mathbf{L L} / ?$ & $1.79(1.43,2.23)$ & $0.0 \%$ & 0.89 & 4 \\
\hline & $\begin{array}{l}\text { Almeida } 2002 \\
\text { [23] }\end{array}$ & $\begin{array}{l}\text { Current versus } \\
\text { never/non-smokers }\end{array}$ & $?$ & $1.99(1.33,2.98)$ & $56.5 \%$ & $\sim$ & 7 \\
\hline & Peters 2008 [59] & $\begin{array}{l}\text { Current versus } \\
\text { never/non-smokers }\end{array}$ & ML/LL/? & $1.59(1.15,2.20)$ & $69.9 \%$ & 0.19 & 8 \\
\hline & Zhong 2015 [22] & Ever versus never & LL & $1.12(1.00,1.26)$ & $55.9 \%$ & $<0.01$ & 23 \\
\hline & $\begin{array}{l}\text { Almeida } 2002 \\
\text { [23] }\end{array}$ & Ever versus never & $?$ & $1.10(0.94,1.29)$ & $93.5 \%$ & 0.53 & 7 \\
\hline & Zhong 2015 [22] & Former versus never & LL & $1.04(0.96,1.13)$ & $2.8 \%$ & $<0.01$ & 13 \\
\hline & $\mathrm{Xu} 2015$ [20] & Former versus never & & $1.00(0.92,1.08)$ & $0.0 \%$ & 0.27 & 9 \\
\hline & Peters 2008 [59] & Former versus never & $?$ & $0.99(0.81,1.23)$ & $46.8 \%$ & 0.79 & 8 \\
\hline \multicolumn{8}{|l|}{ Medical } \\
\hline Arthritis & Xu 2015 [20] & $\begin{array}{l}\text { History of arthritis } \\
\text { (self-report) }\end{array}$ & $\mathrm{LL} / ?$ & $0.63(0.42,0.84)$ & $0.0 \%$ & 0.83 & 2 \\
\hline \multirow[t]{2}{*}{ Atrial fibrillation } & $\begin{array}{l}\text { Kalantarian } 2013 \\
\quad[60]\end{array}$ & $\begin{array}{l}\text { Yes versus no (ECG, } \\
\text { medical history, ICD-9, } \\
\text { unclear) }\end{array}$ & LL & $1.47(0.92,2.34)$ & $68.2 \%$ & $\sim$ & 3 \\
\hline & Xu 2015 [20] & $\begin{array}{l}\text { Yes versus no (medical } \\
\text { records, self-report } \\
\text { health questionnaire) }\end{array}$ & LL & $1.29(0.97,1.60)$ & $60.6 \%$ & 0.94 & 3 \\
\hline \multirow[t]{11}{*}{ BMI } & Anstey 2011 [17] & $\begin{array}{l}\text { Change (increase) } \\
\text { continuous measures of } \\
\text { BMI }\end{array}$ & LL & $0.72(0.62,0.84)$ & $71.5 \%$ & $\sim$ & 2 \\
\hline & Xu 2015 [20] & $\begin{array}{l}\text { High BMI }(>28 / 30) \text { in } \\
\text { midlife versus normal }\end{array}$ & ML/LL/? & $1.61(1.11,2.12)$ & $69.2 \%$ & 0.11 & 6 \\
\hline & Xu 2015 [20] & $\begin{array}{l}\text { High BMI } \\
\text { (>25-30/abdominal } \\
\text { obesity/BMI increase) in } \\
\text { late-life }\end{array}$ & $\mathbf{L L} / ?$ & $0.80(0.64,0.97)$ & $72.9 \%$ & 0.95 & 12 \\
\hline & Anstey 2011 [17] & Obese versus normal & ML/LL & $2.04(1.59,2.69)$ & $82.8 \%$ & $\sim$ & 3 \\
\hline & Loef 2013 [44] & Obese versus normal & ML/LL & $1.98(1.24,3.14)$ & - & - & 4 \\
\hline & Meng 2014 [61] & Obese versus normal & ML & $1.88(1.32,2.69)$ & $59.1 \%$ & 0.55 & 5 \\
\hline & $\begin{array}{l}\text { Beydoun } 2008 \\
\text { [45] }\end{array}$ & Obese versus normal & ML/LL & $1.80(1.00,3.29)$ & - & $<0.01$ & 4 \\
\hline & Anstey 2011 [17] & Obese versus not Obese & LL & $1.46(0.97,2.21)$ & $42.3 \%$ & $\sim$ & 2 \\
\hline & Anstey 2011 [17] & Overweight versus normal & ML/LL & $1.35(1.19,1.54)$ & $92.0 \%$ & $\sim$ & 3 \\
\hline & Loef 2013 [44] & Overweight versus normal & ML/LL & $1.44(0.96,2.15)$ & - & - & 4 \\
\hline & Anstey 2011 [17] & Underweight versus normal & ML/LL & $1.96(1.32,2.92)$ & $69.1 \%$ & $\sim$ & 3 \\
\hline
\end{tabular}


Table 2

(Continued)

\begin{tabular}{|c|c|c|c|c|c|c|c|}
\hline Risk Factor & Short reference & Exposure measure & Age group* & RR & $I^{2}(\%)$ & Bias (Egger's $p$ ) & $\bar{n}$ \\
\hline \multirow[t]{2}{*}{ Cancer } & Ma 2014 [62] & $\begin{array}{l}\text { History of cancer versus } \\
\text { none (ICD code } \\
\text { diagnosis) }\end{array}$ & LL & $0.63(0.56,0.72)$ & $0.0 \%$ & 0.28 & 5 \\
\hline & Xu 2015 [20] & $\begin{array}{l}\text { Yes versus no } \\
\text { (Questionnaire/self- } \\
\text { report, ASL-Mi1 tumor } \\
\text { registry) }\end{array}$ & $\mathbf{L L} / ?$ & $0.65(0.57,0.73)$ & $6.7 \%$ & 0.81 & 6 \\
\hline $\begin{array}{l}\text { Carotid } \\
\text { atherosclerosis }\end{array}$ & Xu 2015 [20] & $\begin{array}{l}\text { Yes versus no (carotid } \\
\text { medina wall thickness) }\end{array}$ & & $1.65(1.03,2.26)$ & $31.1 \%$ & $\sim$ & 2 \\
\hline \multirow[t]{7}{*}{ Cholesterol } & Anstey 2017 [63] & $\begin{array}{l}\text { High cholesterol }(>6.5 \\
\text { mmol/l) versus } \\
\text { non-high-midlife }\end{array}$ & ML & $2.14(1.33,3.44)$ & $12.9 \%$ & $\sim$ & 3 \\
\hline & Meng 2014 [61] & $\begin{array}{l}\text { High cholesterol }(>6.5 \\
\mathrm{mmol} / \mathrm{l}) \text { versus non-high }\end{array}$ & ML & $1.72(1.32,2.24)$ & $8.5 \%$ & possible $^{\wedge}$ & 4 \\
\hline & Xu 2015 [20] & $\begin{array}{l}\text { Elevated serum total } \\
\text { cholesterol level }\end{array}$ & ML/LL/? & $1.07(0.89,1.28)$ & $59.9 \%$ & 0.02 & 16 \\
\hline & $\begin{array}{l}\text { Daviglus } 2011 \\
\text { [56] }\end{array}$ & $\begin{array}{l}\text { Highest versus lowest } \\
\text { quartile }\end{array}$ & $?$ & $0.85(0.65,1.12)$ & - & $\sim$ & 3 \\
\hline & Anstey 2017 [63] & $\begin{array}{l}\text { Highest versus lowest } \\
\text { quartile-Total } \\
\text { cholesterol, late-life }\end{array}$ & LL & $0.93(0.69,1.26)$ & $50.5 \%$ & 0.28 & 4 \\
\hline & Anstey 2017 [63] & Low HDL-C & LL & $0.78(0.54,1.13)$ & $65.4 \%$ & $\sim$ & 3 \\
\hline & Anstey 2008 [17] & $\begin{array}{l}\text { Second versus lowest } \\
\text { quartile-total cholesterol }\end{array}$ & LL & $0.85(0.67,1.10)$ & $40.1 \%$ & $\sim$ & 3 \\
\hline \multirow[t]{4}{*}{ Depression } & $\begin{array}{l}\text { Cherbuin } 2015 \\
\text { [14] }\end{array}$ & $\begin{array}{l}\text { Categorical clinical } \\
\text { thresholds }(>20 / 21 \\
\text { CES-D or equivalent })\end{array}$ & LL & $2.04(1.40,2.98)$ & $54.9 \%$ & possible $^{\wedge}$ & 10 \\
\hline & Diniz 2013 [24] & $\begin{array}{l}\text { Continuous (mostly CES-D } \\
\text { \& variants) }\end{array}$ & $?$ & $1.65(1.42,1.92)$ & $2.0 \%$ & absent $^{\wedge}$ & 17 \\
\hline & $\mathrm{Xu} 2015$ [20] & $\begin{array}{l}\text { Continuous (self-reporting, } \\
\text { CES-D, HAM, } \\
\text { Questionnaire, DSM-IV, } \\
\text { Diagnosis, CAMDEX, } \\
\text { Neuropsychiatric } \\
\text { interview, SCL-90) }\end{array}$ & $\mathbf{L L} / ?$ & $1.08(1.04,1.13)$ & $40.3 \%$ & 0.00 & 24 \\
\hline & $\begin{array}{l}\text { Cherbuin } 2015 \\
\text { [14] }\end{array}$ & $\begin{array}{c}\text { Continuous symptomology } \\
\text { measures-CES-D, HAM, } \\
\text { GDS, SCL-90, the NEO }\end{array}$ & LL & $1.06(1.02,1.10)$ & $62.1 \%$ & possible $^{\wedge}$ & 10 \\
\hline \multirow[t]{8}{*}{ Diabetes } & Zhang 2017 [64] & Any diabetes (Type I or II) & $?$ & $1.53(1.42,1.63)$ & $18.5 \%$ & absent $^{\wedge}$ & 17 \\
\hline & Meng 2014 [61] & Any diabetes (Type I or II) & ML/LL & $1.40(1.25,1.57)$ & $10.6 \%$ & - & 4 \\
\hline & $\begin{array}{l}\text { Vagelatos } 2013 \\
\quad[16]\end{array}$ & $\begin{array}{l}\text { Type II diabetes, self-report } \\
\text { and blood sampling }\end{array}$ & ML/LL & $1.57(1.41,1.75)$ & $38.7 \%$ & 0.22 & 15 \\
\hline & Gudala 2013 [65] & $\begin{array}{l}\text { Type II diabetes } \\
\text { (self-reported, registry- } \\
\text { based/antidiabetics } \\
\text { use) }\end{array}$ & ML/LL & $1.56(1.41,1.73)$ & $9.8 \%$ & 0.93 & 20 \\
\hline & Cheng 2012 [48] & $\begin{array}{l}\text { Type II diabetes (according } \\
\text { to standard criteria) }\end{array}$ & ML/LL & $1.54(1.40,1.70)$ & $71.7 \%$ & $<0.01$ & 18 \\
\hline & Lu 2009 [15] & $\begin{array}{l}\text { Type II diabetes (medical } \\
\text { history, laboratory test, } \\
\text { antidiabetic medications) }\end{array}$ & LL & $1.39(1.16,1.66)$ & $0.0 \%$ & $<0.01$ & 8 \\
\hline & Xu 2015 [20] & $\begin{array}{l}\text { Type II diabetes } \\
\text { (self-report, family } \\
\text { report) }\end{array}$ & ML/LL & $1.33(1.14,1.52)$ & $70.4 \%$ & 0.06 & 22 \\
\hline & $\begin{array}{l}\text { Vagelatos } 2013 \\
\text { [16] }\end{array}$ & $\begin{array}{l}\text { Type II diabetes, self-report } \\
\text { and blood sampling }\end{array}$ & ML/LL & $1.57(1.41,1.75)$ & $38.7 \%$ & 0.22 & 15 \\
\hline \multirow[t]{2}{*}{ Homocysteine } & $\begin{array}{l}\text { Van Dam } 2009 \\
\text { [21] }\end{array}$ & Hyperhomocysteinema & LL & $2.50(1.38,4.56)$ & $81.6 \%$ & $\sim$ & 3 \\
\hline & $\mathrm{Xu} 2015$ [20] & $\begin{array}{l}\text { High total homocysteine } \\
\text { levels }\end{array}$ & ML/LL/? & $1.15(1.09,1.23)$ & $45.0 \%$ & 0.00 & 8 \\
\hline
\end{tabular}


Table 2

(Continued)

\begin{tabular}{|c|c|c|c|c|c|c|c|}
\hline Risk Factor & Short reference & Exposure measure & Age group* & RR & $I^{2}(\%)$ & Bias (Egger's $p$ ) & $\bar{n}$ \\
\hline \multirow[t]{4}{*}{ Hormones } & Wang 2016 [66] & $\begin{array}{l}\text { High versus normal levels } \\
\text { of thyrotropin }\end{array}$ & LL & $1.70(1.18,2.45)$ & $42.2 \%$ & 0.75 & 2 \\
\hline & Wang 2016 [66] & $\begin{array}{l}\text { Low versus normal levels of } \\
\text { thyrotropin }\end{array}$ & LL & $1.69(1.31,2.19)$ & $38.0 \%$ & 0.74 & 4 \\
\hline & Lv 2016 [67] & $\begin{array}{l}\text { Low plasma testosterone (in } \\
\text { elderly men) }\end{array}$ & $?$ & $1.48(1.12,1.96)$ & $47.2 \%$ & 0.15 & 7 \\
\hline & Wang 2016 [66] & $\begin{array}{l}\text { Per SD increment in } \\
\text { thyrotropin levels }\end{array}$ & LL & $0.89(0.78,1.01)$ & $31.3 \%$ & 0.01 & 6 \\
\hline \multirow[t]{13}{*}{ Hyper/Hypotension } & Meng 2014 [61] & $\begin{array}{l}\text { All combined-high SBP, } \\
\text { DBP, hypertension }\end{array}$ & ML/LL & $1.31(1.01,1.70)$ & $45.7 \%$ & - & 5 \\
\hline & Meng 2014 [61] & High DBP & ML/LL & $2.38(1.34,4.23)$ & $0.0 \%$ & - & 3 \\
\hline & Meng 2014 [61] & High SBP & ML/LL & $1.77(0.93,3.37)$ & $0.0 \%$ & - & 3 \\
\hline & Xu 2015 [20] & Higher SBP & $?$ & $1.02(0.92,1.13)$ & $68.7 \%$ & $<0.01$ & 28 \\
\hline & Meng 2014 [61] & Hypertension versus none & ML/LL & $1.10(0.88,1.37)$ & $48.6 \%$ & - & 2 \\
\hline & Guan 2011 [65] & Hypertension versus none & ML/LL & $1.01(0.87,1.18)$ & $37.2 \%$ & - & 9 \\
\hline & Xu 2015 [20] & Lower DBP & $\mathrm{LL} / ?$ & $1.14(0.89,1.39)$ & $60.0 \%$ & $<0.01$ & 6 \\
\hline & Power 2011 [68] & Per $10 \mathrm{mmHg}$ DBP & ML & $0.93(0.84,1.04)$ & $12.4 \%$ & 0.85 & 4 \\
\hline & Power 2011 [68] & Per 10 mmHg DBP & LL & $0.94(0.85,1.04)$ & $14.0 \%$ & 0.45 & 5 \\
\hline & Power 2011 [68] & $\begin{array}{l}\text { Per } 10 \mathrm{mmHg} \text { increment } \\
\text { SBP }\end{array}$ & ML & $0.95(0.90,1.00)$ & $69.4 \%$ & $\sim$ & 4 \\
\hline & Power 2011 [68] & $\begin{array}{l}\text { Per } 10 \mathrm{mmHg} \text { increment } \\
\text { SBP }\end{array}$ & LL & $0.95(0.91,1.00)$ & $0.0 \%$ & 0.54 & 5 \\
\hline & Sharp 2011 [69] & $\begin{array}{l}\text { History of/current } \\
\text { hypertension }\end{array}$ & $?$ & $1.59(1.29,1.95)$ & $37.4 \%$ & $<0.01$ & 6 \\
\hline & Power 2011 [68] & History of hypertension & ML/LL & $0.98(0.80,1.19)$ & $41.8 \%$ & 0.69 & 12 \\
\hline \multirow{2}{*}{$\begin{array}{l}\text { Inflammatory } \\
\text { markers }\end{array}$} & Koyama 2013 [70] & $\mathrm{C}$-reactive protein & LL & $1.36(1.13,1.63)$ & $40.3 \%$ & $\sim$ & 3 \\
\hline & Koyama 2013 [70] & Interleukin-6 & LL & $1.15(0.84,1.59)$ & $0.0 \%$ & $\sim$ & 4 \\
\hline $\begin{array}{l}\text { Metabolic } \\
\text { syndrome }\end{array}$ & $\mathrm{Xu} 2015$ [20] & NCEP ATP III criteria & $\mathbf{L L} /$ ? & $0.71(0.49,0.93)$ & $36.5 \%$ & 0.30 & 4 \\
\hline $\begin{array}{l}\text { Peripheral artery } \\
\text { disease }\end{array}$ & Xu 2015 [20] & $\begin{array}{l}\text { Ankle to Brachial } \\
\text { Index }<0.9-11\end{array}$ & $\mathrm{LL} / ?$ & $1.68(0.97,2.38)$ & $0.0 \%$ & 0.51 & 2 \\
\hline Renal Disease & Xu 2015 [20] & $\begin{array}{l}\text { eGFR (MDRD), I/SCr, } \\
\text { questionnaire }\end{array}$ & $\mathrm{LL} / ?$ & $1.13(0.68,1.59)$ & $0.0 \%$ & 0.67 & 3 \\
\hline Serum uric acid & Du 2016 [71] & Serum uric acid levels & $?$ & $0.66(0.52,0.85)$ & $6.0 \%$ & low risk ${ }^{\wedge}$ & 3 \\
\hline \multirow[t]{2}{*}{ Stroke } & Xu 2015 [20] & $\begin{array}{l}\text { Self-reported history of } \\
\text { stroke }\end{array}$ & $\mathrm{LL} / ?$ & $0.97(0.71,1.24)$ & $40.9 \%$ & 0.03 & -9 \\
\hline & Zhou 2015 [72] & $\begin{array}{l}\text { Stroke diagnosis based on } \\
\text { the International } \\
\text { Classification of Diseases }\end{array}$ & LL & $1.59(1.25,2.02)$ & $0.0 \%$ & $\sim$ & 5 \\
\hline \multirow[t]{3}{*}{ TBI } & Xu 2015 [20] & $\begin{array}{l}\text { Head trauma with/without } \\
\text { loss of consciousness }\end{array}$ & $\mathrm{LL} / ?$ & $1.18(0.89,1.47)$ & $7.5 \%$ & 0.16 & 6 \\
\hline & Li 2017 [73] & Prior TBI & $\mathbf{L L} / ?$ & $1.24(1.04,1.49)$ & 26.8 & 0.32 & 8 \\
\hline & Perry 2016 [74] & Prior TBI & $?$ & $0.95(0.58,1.54)$ & $51.4 \%$ & 0.83 & 7 \\
\hline \multicolumn{8}{|l|}{ Pharmacological } \\
\hline \multirow[t]{2}{*}{ Antacids } & Virk 2015 [75] & $\begin{array}{l}\text { Aluminum containing } \\
\text { antacids }\end{array}$ & $?$ & $0.70(0.30,1.80)$ & $0.0 \%$ & ns & 2 \\
\hline & Virk 2015 [75] & Antacid & $?$ & $0.83(0.39,1.78)$ & $0.0 \%$ & ns & 2 \\
\hline \multirow[t]{4}{*}{ Antihypertensives } & $\mathrm{Xu} 2015[20]$ & Anti-hypertensives & $\mathrm{LL} / ?$ & $0.71(0.59,0.83)$ & $52.7 \%$ & 0.36 & 5 \\
\hline & Xu 2017 [38] & Anti-hypertensives & LL & $0.83(0.64,1.07)$ & $40.5 \%$ & possible ${ }^{\wedge}$ & 6 \\
\hline & $\begin{array}{l}\text { Chang-Quan } 2011 \\
\text { [76] }\end{array}$ & Anti-hypertensives & ML/LL/? & $0.92(0.79,1.08)$ & $0.0 \%$ & 0.66 & 5 \\
\hline & Guan 2011 [77] & Anti-hypertensives & ML/LL & $0.92(0.79,1.08)$ & $0.0 \%$ & 0.66 & 5 \\
\hline \multirow{5}{*}{$\begin{array}{l}\text { Anti- } \\
\text { inflammatories }\end{array}$} & Wang 2015 [78] & Aspirin & $\mathbf{L L} / ?$ & $0.74(0.57,0.97)$ & $67.9 \%$ & - & 8 \\
\hline & Etminan 2003 [79] & Aspirin & ML/LL & $0.85(0.71,1.03)$ & $80.5 \%$ & 0.90 & 5 \\
\hline & Wang 2015 [78] & Non-aspirin NSAIDs & $\mathbf{L L} / ?$ & $0.61(0.43,0.88)$ & $68.6 \%$ & 0.04 & 7 \\
\hline & Szekely 2004 [25] & $\begin{array}{l}\text { NSAIDs-exposure for } 2 \text { or } \\
\text { more years }\end{array}$ & ML/LL/? & $0.42(0.26,0.66)$ & $0.0 \%$ & $\sim$ & 3 \\
\hline & $\mathrm{Xu} 2015$ [20] & NSAIDs & $\mathrm{LL} / ?$ & $0.67(0.44,0.90)$ & $65.8 \%$ & $<0.01$ & 9 \\
\hline
\end{tabular}


Table 2

(Continued)

\begin{tabular}{|c|c|c|c|c|c|c|c|}
\hline Risk Factor & Short reference & Exposure measure & Age group* & $\mathrm{RR}$ & $I^{2}(\%)$ & Bias (Egger's $p$ ) & $\bar{n}$ \\
\hline & Szekely 2004 [25] & NSAIDs-lifetime exposure & ML/LL/? & $0.74(0.62,0.89)$ & - & absent $^{\wedge}$ & 4 \\
\hline & Wang 2015 [78] & All NSAIDS & $\mathbf{L L} /$ ? & $0.69(0.56,0.86)$ & $79.7 \%$ & 0.10 & 12 \\
\hline & Etminan 2003 [79] & All NSAIDs & ML/LL & $0.84(0.54,1.05)$ & $62.3 \%$ & 0.95 & 6 \\
\hline \multirow[t]{3}{*}{ HRT } & LeBlanc 2001 [80] & Any use versus never use & LL & $0.50(0.30,0.80)$ & $0.0 \%$ & $\sim$ & 2 \\
\hline & $\mathrm{Xu} 2015$ [20] & Any use versus never use & $\mathbf{L L} / ?$ & $0.61(0.46,0.76)$ & 38.1 & $<0.01$ & 4 \\
\hline & O’Brien 2014 [81] & Any use versus never use & $?$ & $0.69(0.48,1.00)$ & $31.4 \%$ & 0.78 & 8 \\
\hline Insulin sensitizers & Ye 2016 [82] & $\begin{array}{l}\text { Insulin-sensitizers versus } \\
\text { non-insulin sensitizers }\end{array}$ & $?$ & $0.90(0.55,1.45)$ & - & unobvious $^{\wedge}$ & 2 \\
\hline \multirow[t]{6}{*}{ Statins } & Zhou 2007 [83] & Any use versus non-user & $?$ & $0.90(0.65,1.25)$ & $0.0 \%$ & $\sim$ & 3 \\
\hline & Xu 2015 [20] & $\begin{array}{l}\text { Current use versus never } \\
\text { use }\end{array}$ & $\mathrm{LL} /$ ? & $0.59(0.45,0.73)$ & $26.4 \%$ & 0.29 & 5 \\
\hline & Xu 2015 [20] & Former versus never use & $?$ & $1.28(0.69,3.24)$ & $74.6 \%$ & $\sim$ & 2 \\
\hline & $\mathrm{Xu} 2015$ [20] & Longer use versus never use & $?$ & $0.24(0.07,0.70)$ & $0.0 \%$ & $\sim$ & 2 \\
\hline & Wong 2013 [84] & Users versus non-users & $?$ & $0.70(0.60,0.80)$ & $18.2 \%$ & $\operatorname{minimal}^{\wedge}$ & \\
\hline & $\begin{array}{l}\text { Richardson } 2013 \\
\text { [35] }\end{array}$ & Users versus non-users & ML/LL/? & $0.79(0.63,0.99)$ & $91.6 \%$ & 0.38 & 10 \\
\hline \multicolumn{8}{|l|}{ Environmental } \\
\hline \multirow[t]{2}{*}{ Pesticides } & Yan 2016 [85] & Pesticide exposure & LL/? & $1.37(1.08,1.75)$ & $0.0 \%$ & 0.66 & 3 \\
\hline & $\mathrm{Xu} 2015$ [20] & $\begin{array}{l}\text { Occupational exposure to } \\
\text { pesticides }\end{array}$ & $\mathrm{LL} / ?$ & $1.26(0.93,1.59)$ & $5.4 \%$ & 0.78 & 3 \\
\hline
\end{tabular}

Note.*the primary age represented per pooled effect (RR) is denoted by bold text. 'adj' denotes age-adjusted (baseline age is not relevant to measures of self-reported educational attainment), 'ML' denotes midlife (baseline age <65), 'LL late-life (baseline age 65+) and '?' unknown. 'RR' denotes risk ratio, which is the pooled effect size. '-' denotes not reported. ' $\sim$ ' indicates there were too few primary studies to calculate Egger's p. ${ }^{\wedge}$ bias as indicated by visual inspection of funnel plot. Egger's values are as reported in primary reviews, but not a recommended measure of bias when for $n<10$. ' $\mathrm{n}$ ' is the number of primary studies included in the meta-analysis for each RR.

identified for hypo/hypertension. Late-life smoking and overweight/obese BMI in mid- and late-life were consistently associated with increased risk of $\mathrm{VaD}$. Reduced risk was associated with light to moderate alcohol consumption (compared to abstinence) and physical activity. All other meta-analyses included 2-4 primary studies.

Overall heterogeneity of studies within reviews was variable and notably high for the one meta-analysis of cognitive engagement and $\mathrm{AD}$ $\left(\mathrm{I}^{2}=90.5 \%\right)$ and for the range of meta-analyses for diet.

\section{DISCUSSION}

Increased risk for either or all of $\mathrm{AD}, \mathrm{VaD}$, or Any Dementia is associated with low education, diabetes, smoking, depression, midlife obesity, high homocysteine, hypertension (VaD only), atrial fibrillation (Any Dementia only), and social engagement (Any Dementia only). The data for social engagement were limited to late-life and included varied measures. We also found that reduced risk was consistently associated with physical activity, fish consumption, light alcohol consumption, antihypertensives (Any Dementia only), and statin use (AD and Any Dementia). Hearing loss was associated with increased risk of Any Dementia but there has been no review of hearing loss in relation to $\mathrm{AD}$ or $\mathrm{VaD}$ [4], and relatively limited evidence is available for cognitive engagement, dietary pattern, and specific nutrients as protective factors. Note this reflects the limited evidence available for these risk factors currently and it is not a statement about their putative effect.

The gaps in the evidence base on risk factors for dementia are remarkable. By far the majority of data are reported for AD. Data are limited on vascular risk factors for $\mathrm{VaD}$, with only one meta-analysis on physical activity, and no meta-analysis on statins in relation to $\mathrm{VaD}$. A significant number of risk factors have been established primarily in studies of older adults (alcohol, atrial fibrillation, social engagement, cognitive engagement, depression, hormones, metabolic syndrome, peripheral artery disease, renal disease, serum uric acid, stroke, pesticides) thus omitting midlife exposure (which leads to gaps in long term follow-up). Major gaps occur in data from nonEuropean and non-North-American continents. For example, data on BMI are drawn from fewer than $40 \%$ of world regions and there are no meta-analysis data in this review on BMI as a risk factor for dementia from Asian samples. Evidence for stress, inflamma- 
Adequacy of exposure and review quality

Age of exposure: $\square \square \square$ (\% reviews in risk factor) missing latelife midlife

Length of follow-up: $\square \square \square$
Generalisability of reviews by risk factor Recency of reviews: $\square$ Global generalisability: (\% reviews since 2013) (\% regions represented)

Number of reviews identified: $\longrightarrow$ Degree of overlap (CCA): Number of primary studies: 17 slight $\square$ moderate $\square$ high $\square$ very high $\square$

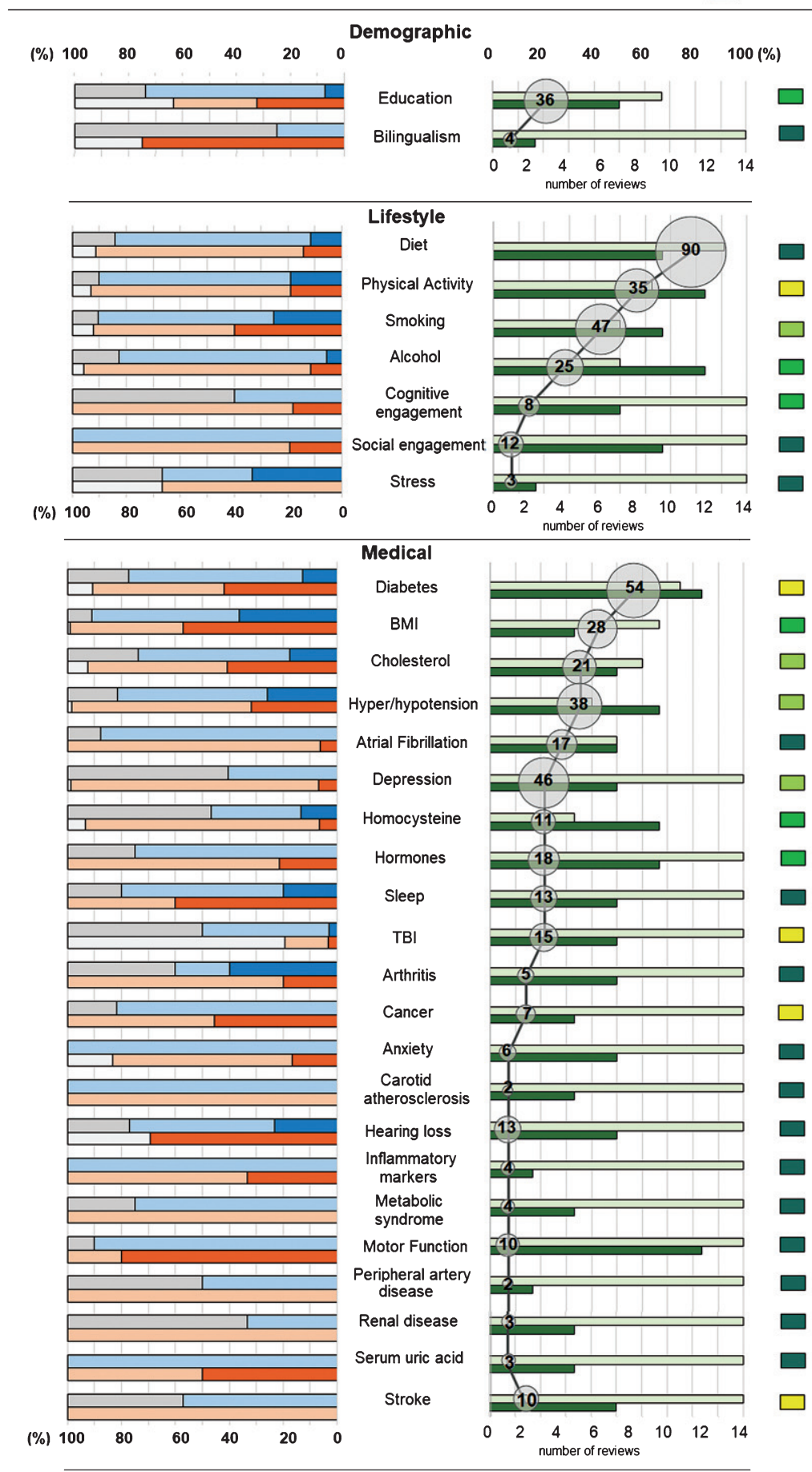

Fig. 3. (Continued) 


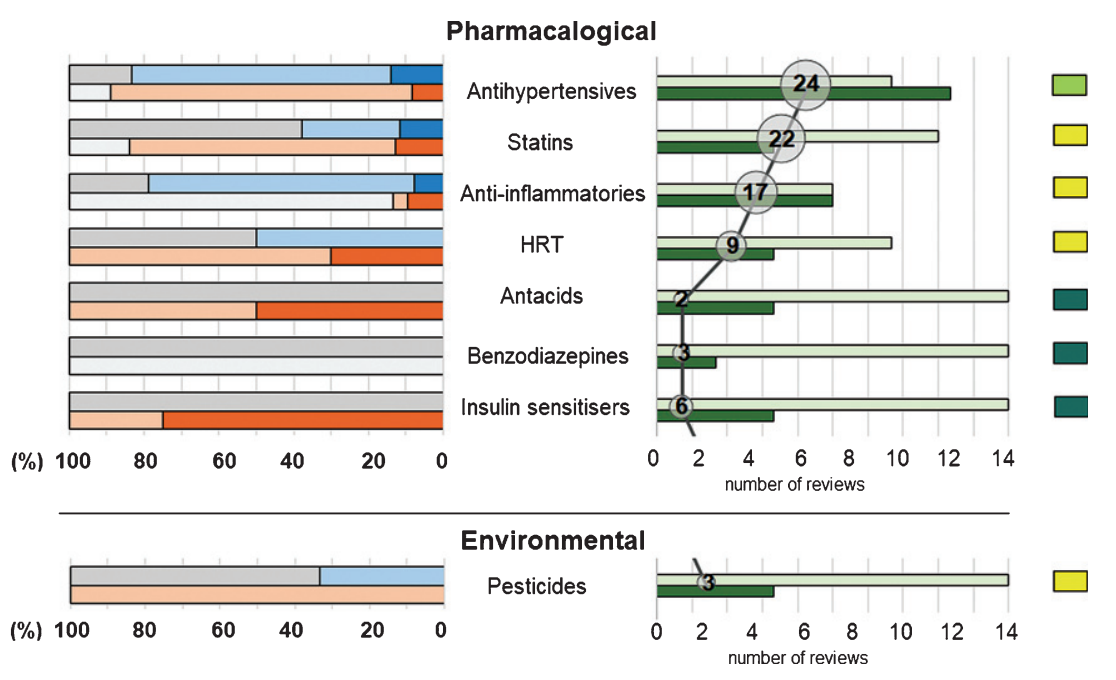

Fig. 3. Body of evidence metrics for all risk factors.

tory markers, and peripheral artery disease is drawn from one region. Sleep and social engagement as risk factors have not been reviewed in relation to dementia subtypes. Although the AMSTAR scores were generally high, we identified a lack of commonly used exposure measures for some risk factors (e.g., cognitive engagement). The AMSTAR rating does not capture some important methodological features that contribute to quality and bias in relation to this specific field and we needed to develop new metrics to capture important causes of bias in this literature.

The strengths of this review include its comprehensiveness and the evaluation of study quality and quantity. Reviews had clinical diagnoses of dementia and exclusion of individuals with dementia at baseline. This review has not considered mediating factors or whether risk factors are proxies for other variables. For example, it is possible that the risk of dementia associated with BMI is mediated by cultural or genetic factors such as Western-style diet and that BMI is a proxy for other socio-cultural factors. It is also possible that genotype interacts with risk exposure such that subgroups of the population may benefit more from risk reducing strategies or be harmed more by specific exposures (e.g., alcohol drinking). In addition, reverse causality was not evaluated and is a particular concern for risk factors identified only in late-life data such as cognitive engagement and $\mathrm{AD}$. Meta-analyses do not include all published studies so the review may not include all the available data on every risk factor reviewed. Another potential source of bias is that selected meta-analyses may over-represent older primary studies which may not be relevant to current cohorts.

Understanding the risk and protective factors influencing cognitive aging and dementia requires a life-course approach and studies with long-term follow-ups. Much work is needed to identify critical time points for exposure, and to establish whether a common set of risk factors applies in different countries, at different ages of exposure, and for different dementia subtypes. Given the overlap of risk factors for dementia with other chronic disease areas, it is economical to adopt global chronic disease strategies for key risk factors such as smoking, insufficient physical activity, diabetes, depression, and hypertension. However, as evidence grows we expect more nuanced approaches to dementia risk reduction will be needed for specific populations and age-groups. The evidence reported in this review may be used to inform guideline development and identify research gaps, and areas where policy is based on strong versus weak evidence. This review provides the best evidence currently available representativeness, quality and quantity of evidence on risk factors for dementia.

\section{ACKNOWLEDGMENTS}

NHMRC Fellowship 1102694 to KJA, NHMRC Dementia Centre for Research Collaboration, NHMRC CRE1100579 to KJA; NeuRA Discovery Grant to KJA. 
Authors' disclosures available online (https:// www.j-alz.com/manuscript-disclosures/19-0181r2).

\section{SUPPLEMENTARY MATERIAL}

The supplementary material is available in the electronic version of this article: http://dx.doi.org/ 10.3233/JAD-190181.

\section{REFERENCES}

[1] Lopez AD, Mathers CD, Ezzati M, Jamison DT, Murray CJ (2006) Global and regional burden of disease and risk factors, 2001: Systematic analysis of population health data. Lancet 367, 1747-1757.

[2] Brookmeyer R, Kawas CH, Abdallah N, Paganini-Hill A, Kim RC, Corrada MM (2016) Impact of interventions to reduce Alzheimer's disease pathology on the prevalence of dementia in the oldest-old. Alzheimers Dement 12, 225-232.

[3] Leshner AI, Landis S, Stroud C, Downey A (2017) Preventing cognitive decline and dementia: A way forward. National Academies of Sciences, Engineering, and Medicine; Health and Medicine Division National Academies Press, Washington, DC.

[4] Livingston G, Sommerlad A, Orgeta V, Costafreda SG, Huntley J, Ames D, Ballard C, Banerjee S, Burns A, CohenMansfield J (2017) Dementia prevention, intervention, and care. Lancet 390, 2673-2734.

[5] Williams JW, Plassman BL, Burke J, Holsinger T, Benjamin S (2010) Preventing Alzheimer's Disease and Cognitive Decline. Evidence Report/Technology Assessment No. 193. (Prepared by the Duke Evidence-based Practice Center under Contract No. HHSA 290-2007-10066-I.) AHRQ Publication No. 10-E005. Agency for Healthcare Research and Quality, Rockville, MD.

[6] National Collaborating Centre for Mental Health (2016) A NICE-SCIE Guideline on supporting people with dementia and their carers in health and social care - Revised. National Clinical Practice Guideline British Psychological Society and Gaskell, United Kingdom.

[7] Ioannidis J (2017) Next-generation systematic reviews: Prospective meta-analysis, individual-level data, networks and umbrella reviews. Br J Sports Med 51, 1456-1458.

[8] Chen Y, Yang K, Marušić A, Qaseem A, Meerpohl JJ, Flottorp S, Akl EA, Schünemann HJ, Chan ES, Falck-Ytter Y (2017) A Reporting tool for practice guidelines in health care: The RIGHT statement. Ann Intern Med 166, 128-132.

[9] Aromataris E, Fernandez R, Godfrey CM, Holly C, Khalil H, Tungpunkom P (2015) Summarizing systematic reviews: Methodological development, conduct and reporting of an umbrella review approach. Int J Evid Based Healthc 13, 132-140.

[10] Román GC, Tatemichi TK, Erkinjuntti T, Cummings J, Masdeu J, Garcia Ja, Amaducci L, Orgogozo J-M, Brun A, Hofman A (1993) Vascular dementia diagnostic criteria for research studies: Report of the NINDS-AIREN International Workshop. Neurology 43, 250-250.

[11] (2013) GRADE Handbook, https://gdt.gradepro.org/app/.

[12] Pieper D, Antoine S-L, Mathes T, Neugebauer EA, Eikermann M (2014) Systematic review finds overlapping reviews were not mentioned in every other overview. J Clini Epidemiol 67, 368-375.
[13] Shea BJ, Grimshaw JM, Wells GA, Boers M, Andersson N, Hamel C, Porter AC, Tugwell P, Moher D, Bouter LM (2007) Development of AMSTAR: A measurement tool to assess the methodological quality of systematic reviews. BMC Med Res Methodol 7, 10.

[14] Cherbuin N, Kim S, Anstey KJ (2015) Dementia risk estimates associated with measures of depression: A systematic review and meta-analysis. BMJ Open 5, e008853.

[15] Lu F-P, Lin K-P, Kuo H-K (2009) Diabetes and the risk of multi-system aging phenotypes: A systematic review and meta-analysis. PloS One 4, e4144.

[16] Vagelatos NT, Eslick GD (2013) Type 2 diabetes as a risk factor for Alzheimer's disease: The confounders, interactions, and neuropathology associated with this relationship. Epidemiol Rev 35, 152-160.

[17] Anstey KJ, Cherbuin N, Budge M, Young J (2011) Body mass index in midlife and late-life as a risk factor for dementia: A meta-analysis of prospective studies. Obes Rev 12, e426-437.

[18] Caamano-Isorna F, Corral M, Montes-Martinez A, Takkouche B (2006) Education and dementia: A metaanalytic study. Neuroepidemiology 26, 226-232.

[19] Xu W, Tan L, Wang HF, Tan MS, Tan L, Li JQ, Zhao QF, Yu JT (2016) Education and risk of dementia: Dose-response meta-analysis of prospective cohort studies. Mol Neurobiol $\mathbf{5 3}, 3113-3123$

[20] Xu W, Tan L, Wang HF, Jiang T, Tan MS, Tan L, Zhao QF, Li JQ, Wang J, Yu JT (2015) Meta-analysis of modifiable risk factors for Alzheimer's disease. J Neurol Neurosurg Psychiatry 86, 1299-1306.

[21] Van Dam F, Van Gool WA (2009) Hyperhomocysteinemia and Alzheimer's disease: A systematic review. Arch Gerontol Geriatr 48, 425-430.

[22] Zhong G, Wang Y, Zhang Y, Guo JJ, Zhao Y (2015) Smoking is associated with an increased risk of dementia: A metaanalysis of prospective cohort studies with investigation of potential effect modifiers. PLoS One 10, e0118333.

[23] Almeida OP, Hulse GK, Lawrence D, Flicker L (2002) Smoking as a risk factor for Alzheimer's disease: Contrasting evidence from a systematic review of case-control and cohort studies. Addiction 97, 15-28.

[24] Diniz BS, Butters MA, Albert SM, Dew MA, Reynolds CF, 3rd (2013) Late-life depression and risk of vascular dementia and Alzheimer's disease: Systematic review and meta-analysis of community-based cohort studies. Br J Psychiatry 202, 329-335.

[25] Szekely CA, Thorne JE, Zandi PP, Ek M, Messias E, Breitner JC, Goodman SN (2004) Nonsteroidal antiinflammatory drugs for the prevention of Alzheimer's disease: A systematic review. Neuroepidemiology 23, 159-169.

[26] Wang J, Tan L, Wang H-F, Tan C-C, Meng X-F, Wang C, Tang S-W, Yu J-T (2015) Anti-inflammatory drugs and risk of Alzheimer's disease: An updated systematic review and meta-analysis. J Alzheimers Dis 44, 385-396.

[27] Anstey KJ, Mack HA, Cherbuin N (2009) Alcohol consumption as a risk factor for dementia and cognitive decline: Meta-analysis of prospective studies. Am J Geriatr Psychiatry 17, 542-555.

[28] Hamer M, Chida Y (2009) Physical activity and risk of neurodegenerative disease: A systematic review of prospective evidence. Psychol Med 39, 3-11.

[29] Xu W, Wang HF, Wan Y, Tan CC, Yu JT, Tan L (2017) Leisure time physical activity and dementia risk: A doseresponse meta-analysis of prospective studies. BMJ Open 7, $\mathrm{e} 014706$. 
[30] Wu S, Ding Y, Wu F, Li R, Hou J, Mao P (2015) Omega3 fatty acids intake and risks of dementia and Alzheimer's disease: A meta-analysis. Neurosci Biobehav Rev 48, 1-9.

[31] Zhang Y, Chen J, Qiu J, Li Y, Wang J, Jiao J (2016) Intakes of fish and polyunsaturated fatty acids and mildto-severe cognitive impairment risks: A dose-response meta-analysis of 21 cohort studies. Am J Clin Nutr 103, 330-340.

[32] Liu Q-P, Wu Y-F, Cheng H-Y, Xia T, Ding H, Wang H, Wang Z-M, Xu Y (2016) Habitual coffee consumption and risk of cognitive decline/dementia: A systematic review and meta-analysis of prospective cohort studies. Nutrition 32, 628-636

[33] Peters R, Peters J, Warner J, Beckett N, Bulpitt C (2008) Alcohol, dementia and cognitive decline in the elderly: A systematic review. Age Ageing 37, 505-512.

[34] Swiger KJ, Manalac RJ, Blumenthal RS, Blaha MJ, Martin SS (2013) Statins and cognition: A systematic review and meta-analysis of short- and long-term cognitive effects. Mayo Clin Proc 88, 1213-1221.

[35] Richardson K, Schoen M, French B, Umscheid CA, Mitchell MD, Arnold SE, Heidenreich PA, Rader DJ, deGoma EM (2013) Statins and cognitive function: A systematic review. Ann Intern Med 159, 688-697.

[36] Blondell SJ, Hammersley-Mather R, Veerman JL (2014) Does physical activity prevent cognitive decline and dementia?: A systematic review and meta-analysis of longitudinal studies. BMC Public Health 14, 510.

[37] Tully PJ, Hanon O, Cosh S, Tzourio C (2016) Diuretic antihypertensive drugs and incident dementia risk: A systematic review, meta-analysis and meta-regression of prospective studies. J Hypertens 34, 1027-1035.

[38] Xu G, Bai F, Lin X, Wang Q, Wu Q, Sun S, Jiang C, Liang Q, Gao B (2017) Association between antihypertensive drug use and the incidence of cognitive decline and dementia: A meta-analysis of prospective cohort studies. Biomed Res Int 2017, 4368474.

[39] Cao L, Tan L, Wang HF, Jiang T, Zhu XC, Lu H, Tan MS, Yu JT (2016) Dietary patterns and risk of dementia: A systematic review and meta-analysis of cohort studies. $\mathrm{Mol}$ Neurobiol 53, 6144-6154.

[40] de Almondes KM, Costa MV, Malloy-Diniz LF, Diniz BS (2016) Insomnia and risk of dementia in older adults: Systematic review and meta-analysis. J Psychiatr Res 77, 109-115.

[41] Kim HB, Myung SK, Lee SM, Park YC (2016) Longer duration of sleep and risk of cognitive decline: A meta-analysis of observational studies. Neuroepidemiology 47, 171-180.

[42] Kuiper JS, Zuidersma M, Oude Voshaar RC, Zuidema SU, van den Heuvel ER, Stolk RP, Smidt N (2015) Social relationships and risk of dementia: A systematic review and meta-analysis of longitudinal cohort studies. Ageing Res Rev 22, 39-57.

[43] Pedditizi E, Peters R, Beckett N (2016) The risk of overweight/obesity in mid-life and late life for the development of dementia: A systematic review and meta-analysis of longitudinal studies. Age Ageing 45, 14-21.

[44] Loef M, Walach H (2013) Midlife obesity and dementia: Meta-analysis and adjusted forecast of dementia prevalence in the United States and China. Obesity (Silver Spring) 21, E51-55.

[45] Beydoun MA, Beydoun HA, Wang Y (2008) Obesity and central obesity as risk factors for incident dementia and its subtypes: A systematic review and meta-analysis. Obes Rev 9, 204-218.
[46] Ford AH, Hankey GJ, Yeap BB, Golledge J, Flicker L, Almeida OP (2018) Hearing loss and the risk of dementia in later life. Maturitas 112, 1-11.

[47] Chatterjee S, Peters SA, Woodward M, Mejia Arango S, Batty GD, Beckett N, Beiser A, Borenstein AR, Crane PK, Haan M, Hassing LB, Hayden KM, Kiyohara Y, Larson EB, Li CY, Ninomiya T, Ohara T, Peters R, Russ TC, Seshadri S, Strand BH, Walker R, Xu W, Huxley RR (2016) Type 2 diabetes as a risk factor for dementia in women compared with men: A pooled analysis of 2.3 million people comprising more than 100,000 cases of dementia. Diabetes Care 39, 300-307.

[48] Cheng G, Huang C, Deng H, Wang H (2012) Diabetes as a risk factor for dementia and mild cognitive impairment: A meta-analysis of longitudinal studies. Intern Med $\mathbf{J} \mathbf{4 2}$, 484-491.

[49] Anstey KJ, von Sanden C, Salim A, O'Kearney R (2007) Smoking as a risk factor for dementia and cognitive decline: A meta-analysis of prospective studies. Am J Epidemiol 166, 367-378.

[50] Singh B, Parsaik AK, Mielke MM, Erwin PJ, Knopman DS, Petersen RC, Roberts RO (2014) Association of Mediterranean diet with mild cognitive impairment and Alzheimer's disease: A systematic review and metaanalysis. J Alzheimers Dis 39, 271-282.

[51] Wu Y, Pei Y, Wang F, Xu D, Cui W (2016) Higher FT4 or TSH below the normal range are associated with increased risk of dementia: A meta-analysis of 11 studies. Sci Rep $\mathbf{6}$, 31975.

[52] Kim YS, Kwak SM, Myung SK (2015) Caffeine intake from coffee or tea and cognitive disorders: A metaanalysis of observational studies. Neuroepidemiology 44, 51-63.

[53] Quintana JLB, Allam MF, Del Castillo AS, Navajas RFC (2007) Alzheimer's disease and coffee: A quantitative review. Neurol Res 29, 91-95.

[54] Shen L, Ji HF (2015) Vitamin D deficiency is associated with increased risk of Alzheimer's disease and dementia: Evidence from meta-analysis. Nutr J 14, 76.

[55] Santos-Lozano A, Pareja-Galeano H, Sanchis-Gomar F, Quindós-Rubial M, Fiuza-Luces C, Cristi-Montero C, Emanuele E, Garatachea N, Lucia A (2016) Physical activity and Alzheimer disease: A protective association. Mayo Clin Proc 91, 999-1020.

[56] Daviglus ML, Plassman BL, Pirzada A, Bell CC, Bowen PE, Burke JR, Connolly ES Jr, Dunbar-Jacob JM, Granieri EC, McGarry K, Patel D, Trevisan M, Williams JW Jr (2011) Risk factors and preventive interventions for Alzheimer disease: State of the science. Arch Neurol 68, 1185-1190.

[57] Beckett MW, Ardern CI, Rotondi MA (2015) A metaanalysis of prospective studies on the role of physical activity and the prevention of Alzheimer's disease in older adults. BMC Geriatr 15, 9.

[58] Bubu OM, Brannick M, Mortimer J, Umasabor-Bubu O, Sebastião YV, Wen Y, Schwartz S, Borenstein AR, Wu Y, Morgan D, Anderson WM (2017) Sleep, cognitive impairment, and Alzheimer's disease: A systematic review and meta-analysis. Sleep 40, doi: 10.1093/sleep/zsw032

[59] Peters R, Poulter R, Warner J, Beckett N, Burch L, Bulpitt C (2008) Smoking, dementia and cognitive decline in the elderly, a systematic review. BMC Geriatr $\mathbf{8}, 36$.

[60] Kalantarian S, Stern TA, Mansour M, Ruskin JN (2013) Cognitive impairment associated with atrial fibrillation: A meta-analysis. Ann Intern Med 158, 338-346. 
[61] Meng XF, Yu JT, Wang HF, Tan MS, Wang C, Tan CC, Tan L (2014) Midlife vascular risk factors and the risk of Alzheimer's disease: A systematic review and metaanalysis. J Alzheimers Dis 42, 1295-1310.

[62] Ma LL, Yu JT, Wang HF, Meng XF, Tan CC, Wang C, Tan L (2014) Association between cancer and Alzheimer's disease: Systematic review and meta-analysis. J Alzheimers Dis 42, 565-573.

[63] Anstey KJ, Ashby-Mitchell K, Peters R (2017) Updating the evidence on the association between serum cholesterol and risk of late-life dementia: Review and meta-analysis. $J$ Alzheimers Dis 56, 215-228.

[64] Zhang J, Chen C, Hua S, Liao H, Wang M, Xiong Y, Cao F (2017) An updated meta-analysis of cohort studies: Diabetes and risk of Alzheimer's disease. Diabetes Res Clin Pract 124, 41-47.

[65] Gudala K, Bansal D, Schifano F, Bhansali A (2013) Diabetes mellitus and risk of dementia: A meta-analysis of prospective observational studies. J Diabetes Investig 4, 640-650.

[66] Wang Y, Sheng Q, Hou X, Wang B, Zhao W, Yan S, Wang Y, Zhao S (2016) Thyrotropin and Alzheimer's disease risk in the elderly: A systematic review and meta-analysis. $\mathrm{Mol}$ Neurobiol 53, 1229-1236.

[67] Lv W, Du N, Liu Y, Fan X, Wang Y, Jia X, Hou X, Wang B (2016) Low testosterone level and risk of Alzheimer's disease in the elderly men: A systematic review and metaanalysis. Mol Neurobiol 53, 2679-2684.

[68] Power MC, Weuve J, Gagne JJ, McQueen MB, Viswanathan A, Blacker D (2011) The association between blood pressure and incident Alzheimer disease: A systematic review and meta-analysis. Epidemiology 22, 646-659.

[69] Sharp SI, Aarsland D, Day S, Sonnesyn H, Alzheimer's Society Vascular Dementia Systematic Review G, Ballard $\mathrm{C}$ (2011) Hypertension is a potential risk factor for vascular dementia: Systematic review. Int J Geriatr Psychiatry 26, 661-669.

[70] Koyama A, O'Brien J, Weuve J, Blacker D, Metti AL, Yaffe K (2013) The role of peripheral inflammatory markers in dementia and Alzheimer's disease: A meta-analysis. J Gerontol A Biol Sci Med Sci 68, 433-440.

[71] Du N, Xu D, Hou X, Song X, Liu C, Chen Y, Wang Y, Li X (2016) Inverse association between serum uric acid levels and Alzheimer's disease risk. Mol Neurobiol 53, 2594-2599.

[72] Zhou J, Yu J-T, Wang H-F, Meng X-F, Tan C-C, Wang J, Wang C, Tan L (2015) Association between stroke and Alzheimer's disease: Systematic review and meta-analysis. J Alzheimers Dis 43, 479-489.

[73] Li Y, Li Y, Li X, Zhang S, Zhao J, Zhu X, Tian G (2017) Head injury as a risk factor for dementia and Alzheimer's disease: A systematic review and meta-analysis of 32 observational studies. PLoS One 12, e0169650.
[74] Perry DC, Sturm VE, Peterson MJ, Pieper CF, Bullock T, Boeve BF, Miller BL, Guskiewicz KM, Berger MS, Kramer JH, Welsh-Bohmer KA (2016) Association of traumatic brain injury with subsequent neurological and psychiatric disease: A meta-analysis. J Neurosurg 124, 511-526.

[75] Virk SA, Eslick GD (2015) Brief Report: Meta-analysis of antacid use and Alzheimer's disease: Implications for the aluminum hypothesis. Epidemiology 26, 769-773.

[76] Chang-Quan H, Hui W, Chao-Min W, Zheng-Rong W, JunWen G, Yong-Hong L, Yan-You L, Qing-Xiu L (2011) The association of antihypertensive medication use with risk of cognitive decline and dementia: A meta-analysis of longitudinal studies. Int J Clin Pract 65, 1295-1305.

[77] Guan J-W, Huang C-Q, Li Y-H, Wan C-M, You C, Wang Z-R, Liu Y-Y, Liu Q-X (2011) No association between hypertension and risk for Alzheimer's disease: A metaanalysis of longitudinal studies. J Alzheimers Dis 27, 799-807.

[78] Wang J, Tan L, Wang H-F, Tan C-C, Meng X-F, Wang C, Tang S-W, Yu J-T (2015) Anti-inflammatory drugs and risk of Alzheimer's disease: An updated systematic review and meta-analysis. J Alzheimers Dis 44, 385-396.

[79] Etminan M, Gill S, Samii A (2003) Effect of non-steroidal anti-inflammatory drugs on risk of Alzheimer's disease: Systematic review and meta-analysis of observational studies. BMJ 327, 128.

[80] LeBlanc ES, Janowsky J, Chan BK, Nelson HD (2001) Hormone replacement therapy and cognition: Systematic review and meta-analysis. JAMA 285, 1489-1499.

[81] O'Brien J, Jackson JW, Grodstein F, Blacker D, Weuve J (2014) Postmenopausal hormone therapy is not associated with risk of all-cause dementia and Alzheimer's disease. Epidemiol Rev 36, 83-103.

[82] Ye F, Luo YJ, Xiao J, Yu NW, Yi G (2016) Impact of insulin sensitizers on the incidence of dementia: A meta-analysis. Dement Geriatr Cogn Disord 41, 251-260.

[83] Zhou B, Teramukai S, Fukushima M (2007) Prevention and treatment of dementia or Alzheimer's disease by statins: A meta-analysis. Dement Geriatr Cogn Disord 23, 194-201.

[84] Wong WB, Lin VW, Boudreau D, Devine EB (2013) Statins in the prevention of dementia and Alzheimer's disease: A meta-analysis of observational studies and an assessment of confounding. Pharmacoepidemiol Drug Saf 22, 345-358.

[85] Yan D, Zhang Y, Liu L, Yan H (2016) Pesticide exposure and risk of Alzheimer's disease: A systematic review and meta-analysis. Sci Rep 6, 32222. 